Nicolas Hubert*, Kadarusman, Arif Wibowo, Frédéric Busson, Domenico Caruso, Sri Sulandari, Nuna Nafiqoh, Laurent Pouyaud, Lukas Rüber, Jean-Christophe Avarre, Fabian Herder, Robert Hanner, Philippe Keith, Renny K. Hadiaty

\title{
DNA Barcoding Indonesian freshwater fishes: challenges and prospects
}

\section{DOI 10.1515/dna-2015-0018}

Received December 12, 2014; accepted September 29, 2015

\begin{abstract}
With 1172 native species, the Indonesian ichthyofauna is among the world's most speciose. Despite that the inventory of the Indonesian ichthyofauna started during the eighteen century, the numerous species descriptions during the last decades highlight that the taxonomic knowledge is still fragmentary. Meanwhile, the fast increase of anthropogenic perturbations during
\end{abstract}

*Corresponding author: Nicolas Hubert, Institut de Recherche pour le Développement (IRD), UMR226 ISE-M, Bât. 22 - CC065, Place Eugène Bataillon, 34095 Montpellier cedex 5, France, E-mail: nicolas.hubert@ ird.fr

Domenico Caruso, Laurent Pouyaud, Jean-Christophe Avarre, Institut de Recherche pour le Développement (IRD), UMR226 ISE-M, Bât. 22 - CC065, Place Eugène Bataillon, 34095 Montpellier cedex 5, France

Nicolas Hubert, Sri Sulandari, Renny K. Hadiaty, Museum Zoologicum Bogoriense (MZB), Division of Zoology, Research Center for Biology, Indonesian Institute of Sciences (LIPI), Jl. Raya Bogor Km46, Cibinong 16911, Java Barat, Indonesia.

Kadarusman, Akademi Perikanan Sorong (APSOR), Kementerian Kelautan dan Perikanan, Jl. Kapitan Pattimura, Tanjung Kasuari, Sorong 98401, Papua Barat, Indonesia.

Arif Wibowo, Research Institute of Inland Fisheries, Agency for Marine and Fisheries Research - Ministry for Marine and Fisheries Affair, Jl. Beringin No. 308, Mariana, Palembang 30763, Sumatera Selatan, Indonesia.

Frédéric Busson, Philippe Keith, Muséum National d'Histoire Naturelle (MNHN), UMR 7208 BOREA (MNHN-CNRS-UPMC-IRD), CP 026, 57 rue Cuvier, 75231 Paris Cedex 05, France.

Domenico Caruso, Nuna Nafiqoh, Jean-Christophe Avarre, Research and Development Institute for Fish Health Control, Indonesian Agency for Marine \& Fisheries Research and Development, Jalan perikanan 12A, Depok, Java Barat, Indonesia

Lukas Rüber, Naturhistorisches Museum der Burgergemeinde Bern, Bernastrasse 15, Bern 3005, Switzerland.

Fabian Herder, Zoologisches Forschungsmuseum Alexander Koenig (ZFMK), Leibniz-Institut für Biodiversität der Tiere, Adenauerallee 160, 53113 Bonn, Germany.

Robert Hanner, Biodiversity Institute of Ontario and Department of Integrative Biology, University of Guelph, Guelph, ON, Canada the last decades is posing serious threats to Indonesian biodiversity. Indonesia, however, is one of the major sources of export for the international ornamental trade and home of several species of high value in aquaculture. The development of new tools for species identification is urgently needed to improve the sustainability of the exploitation of the Indonesian ichthyofauna. With the aim to build comprehensive DNA barcode libraries, the co-authors have started a collective effort to DNA barcode all Indonesian freshwater fishes. The aims of this review are: (1) to produce an overview of the ichthyological researches conducted so far in Indonesia, (2) to present an updated checklist of the freshwater fishes reported to date from Indonesia's inland waters, (3) to highlight the challenges associated with its conservation and management, (4) to present the benefits of developing comprehensive DNA barcode reference libraries for the conservation of the Indonesian ichthyofauna.

Keywords: DNA barcoding;Checklist;Southeast Asia

\section{Introduction}

Biodiversity is not evenly distributed and aggregates in restricted areas, some of which are currently facing massive habitat loss and as such, have been identified as biodiversity hotspots [1]. Among the 26 biodiversity hotspots identified worldwide by Myers and colleagues [1], four are found in Southeast Asia (SEA) including Indo-Burma (Thailand, Cambodia, Laos, Vietnam and Myanmar), Sundaland (Malaysia, Indonesia), Wallacea (Indonesia) and Philippines hotspots. The exceptional concentration of biodiversity hotspots in SEA ranks the region as one of the most diverse together with the Amazon and Congo River watersheds but threat levels actually rank them as the most endangered hotspots to date [2,3]. Among the four biodiversity hotspots identified in SEA, the two Indonesian hotspots are currently the most 
threatened and Sundaland in particular, is the one that experienced the fastest increase of threat levels during the last decade [3]. Including Peninsular Malaysia and the islands of Sumatra, Java and Borneo (Fig. 1), this hotspot exhibits one of the highest species richness and endemism for vertebrates in SEA [2] and freshwater fishes are no exception. For instance, among the 1200 species described in Indonesia, nearly 900 species are observed in the Sundaland hotspot - c.a. 400 endemics - and constitute an important source of incomes from the international trade of ornamental fishes. The impoverishment of the ichthyodiversity in the Indonesian hotspots is of great concern, however, the taxonomic knowledge is still incomplete and scattered in the scientific literature, what arguably bridles the establishment of sounds conservation plans. Filling this gap is currently jeopardized by the fast degradation of the Indonesian natural habitats due to a large array of perturbations including mining, logging activities, land burning for crop cultivation, deforestation for land conversion (e.g. palm plantations) and water contamination [4, 5]. Freshwater fishes are particularly at risk in Indonesia as their persistence is currently jeopardized by the interactions between ecological and biotic (e.g. inland fisheries, introduction of alien species) perturbations resulting in the modification of habitats, destruction of spawning grounds and the decline of populations [6-9].

The inventory of the Indonesian ichthyodiversity is ongoing since the second half of the $18^{\text {th }}$ century. So far, nearly 1200 species of freshwater fishes have been either described or reported from Indonesian inland waters and the rate of species discovery is still high as several tenth of species have been described from Indonesia during the last years [10-12]. The inventory of Indonesian freshwater fishes has been challenged since its earliest developments by several limitations: (1) the Indonesian archipelago hosts nearly 17,000 islands and most of them are remote islands with limited access, (2) due to a complex political history, tracing the type specimens has been sometimes challenging, particularly for the species described before the 1950's [11], (3) the Indonesian ichthyofauna hosts several large radiation of morphologically similar species that have been subject to either multiple descriptions, recurrent systematic revisions or overlooked diversity [11]. Recently, the use of standardized molecular approaches in some remote rivers in Indonesia emphasized that the sole use of morphology in taxonomy was limiting the estimation of species richness in some cases, as observed in Papuan rainbowfishes, for instance [13].

DNA barcoding is a system designed to provide accurate, fast and automatable species identification by using short and standardized gene regions as internal species tags [14]. Initially proposed to circumvent the lack of taxonomists and available tools for species identification [15-17], DNA barcoding has also been foreseen by several authors as a solution to speed up the pace of species discovery and open new perspectives in conservation [1820]. Given their high diversity and dramatic phenotypic

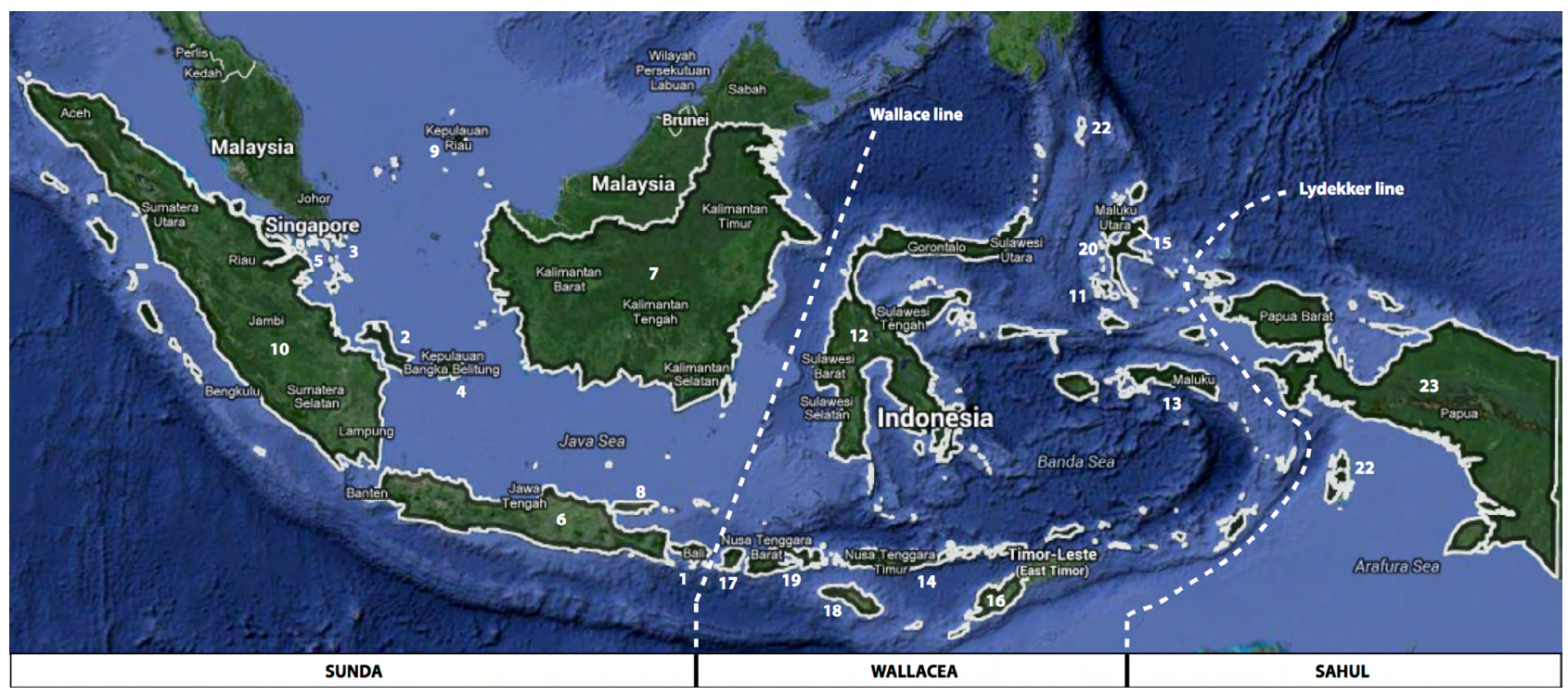

Figure 1. Map of Indonesia including the 23 islands considered in the present review (Appendix) with biogeographic provinces and their boundaries. 1, Bali; 2, Bangka; 3, Batam and Bintan; 4, Belitong; 5, Buru; 6, Java; 7, Kalimantan; 8, Madura; 9 Natuna and Riau; 10, Sumatera; 11, Bacan; 12, Celebes; 13, Ceram; 14, Flores; 15, Halmahera; 16, Indonesian Timor; 17, Lombok; 18, Sumba; 19, Sumbawa; 20, Ternate; 21, Talaud; 22, Aru; 23, Indonesia New Guinea. 
changes during ontogeny, fish identification is not an easy task. After almost a decade, it has become evident that DNA barcoding presents several advantages compared to morphological characters for species identification including: (1) intraspecific phenotypic variation often overlaps that of sister taxa in nature, which can lead to incorrect identifications or species delineations [21,22], (2) DNA barcodes are effective whatever the life stages under scrutiny $[23,24]$ or available biological materials for identification [25, 26], (3) spectacular levels of cryptic diversity have been frequently reported using DNA barcoding [21, 27-31].

An Indonesian initiative to DNA barcode all freshwater fishes is currently handled by the co-authors with the aim to assemble comprehensive DNA barcode libraries for the Indonesian ichthyofauna. In this context, the present review aims at exploring the potential contribution of DNA barcoding for the conservation of the Indonesian ichthyodiversity. First, we provide updated statistics on the Indonesian ichtyodiversity that we compiled from several sources [10-12]. Second, we produce an overview of the ichthyological exploration of Indonesian freshwaters and highlight the major challenges ichthyology is facing in the country. To conclude, we discuss the prospects and challenges associated to the assembly of comprehensive DNA barcode libraries for the Indonesian freshwater fishes.

\section{Indonesian freshwater fishes: general considerations}

The statistics presented here have been compiled from Fishbase [12] and the Eschmeyer's catalog of fishes [32] as available on September 2014. An updated checklist of the SEA freshwater fishes has been recently published by Kottelat [11] but this updated list was not incorporated in fishbase and Eschemeyer at the time we compiled the present statistics and connections with known species range distribution was not available at that time. As our objective is to provide an updated assessment of the distribution of the Indonesian ichthyodiversity, we opted for the conservative list of species name in Fishbase. In this context, the species list provided here (Appendix) is readily available for the DNA barcoding campaign of Indonesian fishes. Species range distributions were compiled from Fishbase species page whenever they were detailed at the island level (Fishbase ${ }^{1}$ in the Appendix) or based on Fishbase Aquamap using valid records only (Fishbase ${ }^{2}$ in the Appendix). Occurrences were refined or invalidated using Eschmeyer [32] and Kottelat's checklists $[10,11]$ whenever additional or contradictory occurrences where found.
To date, 1218 species belonging to 84 families have been reported from Indonesian freshwaters including 1172 native species from 79 families among which 630 species are endemic of the country (Table 1, Appendix). Amongst the 1218 species, 28 are exotic species corresponding to: (1) introduced species (i.e. 21 species from 7 families), among which several belong to exotic families for Indonesian waters (e.g. Cichlidae, Loricariidae, Peociliidae, Serrasalmidae), (2) imported species that have not established yet (i.e. 7 species from 5 families), among which several species belong to 3 exotic families (Poecilidae, Cichlidae, Salmonidae). Finally, 18 species are cited from Indonesian waters but their presence is questionable and is likely to result from misidentifications.

With a density of 0.6 species per $1000 \mathrm{~km}^{2}$ (Table 1), Indonesia hosts one of the world's highest density of fish species ahead of Brazil (0.37 species per 1000km²) and the Democratic Republic of Congo (0.48 species per $1000 \mathrm{~km}^{2}$ ), two countries known to host some the world largest and speciose tropical rivers [12]. The main reasons for this exceptional diversity are the important fragmentation of the rivers across the numerous islands of the archipelago, together with the occurrence of several major biogeographical boundaries in the country including the Wallace and Lydekker lines (Fig. 1) and complex palaeoecological and geological histories [33-37].

The existence of biogeographic provinces in the Indonesian vertebrate fauna is known since the seminal study of Wallace [38] and later by Lydekker in 1895, Weber [39] and Mayr [40]. Two major biogeographical boundaries are still recognized today in Indonesia (Fig. 1) including the Wallace's line separating Sundaland from Wallacea and the Lydekker's line separating Wallacea from Sahul [33]. Yet, two biodiversity hotspots have been described by Myers and colleagues [1] that match those biogeographical boundaries (Sundaland and Wallacea). The distribution of species richness varies among those three regions and Sundaland is the most speciose, both in terms of absolute species richness and number of endemic species with 899 and 431 species, respectively (Table 1). Sundaland also hosts the highest density of species with 0.8 species and 0.38 endemic species per $1000 \mathrm{~km}^{2}$. The endemism, however, is higher in Sahul with nearly 50\% of endemism while hosting only 20 percent of all the Indonesian endemic species.

The family Cyprinidae is the most speciose family of the archipelago with 241 species followed by the families Gobiidae with 122 species, Osphronemidae with 81 species and Bagridae with 60 species (Fig. 2A). The dominant families, however, varies among biogeographical provinces as Sundaland is dominated by the Cyprinidae (231 species; 


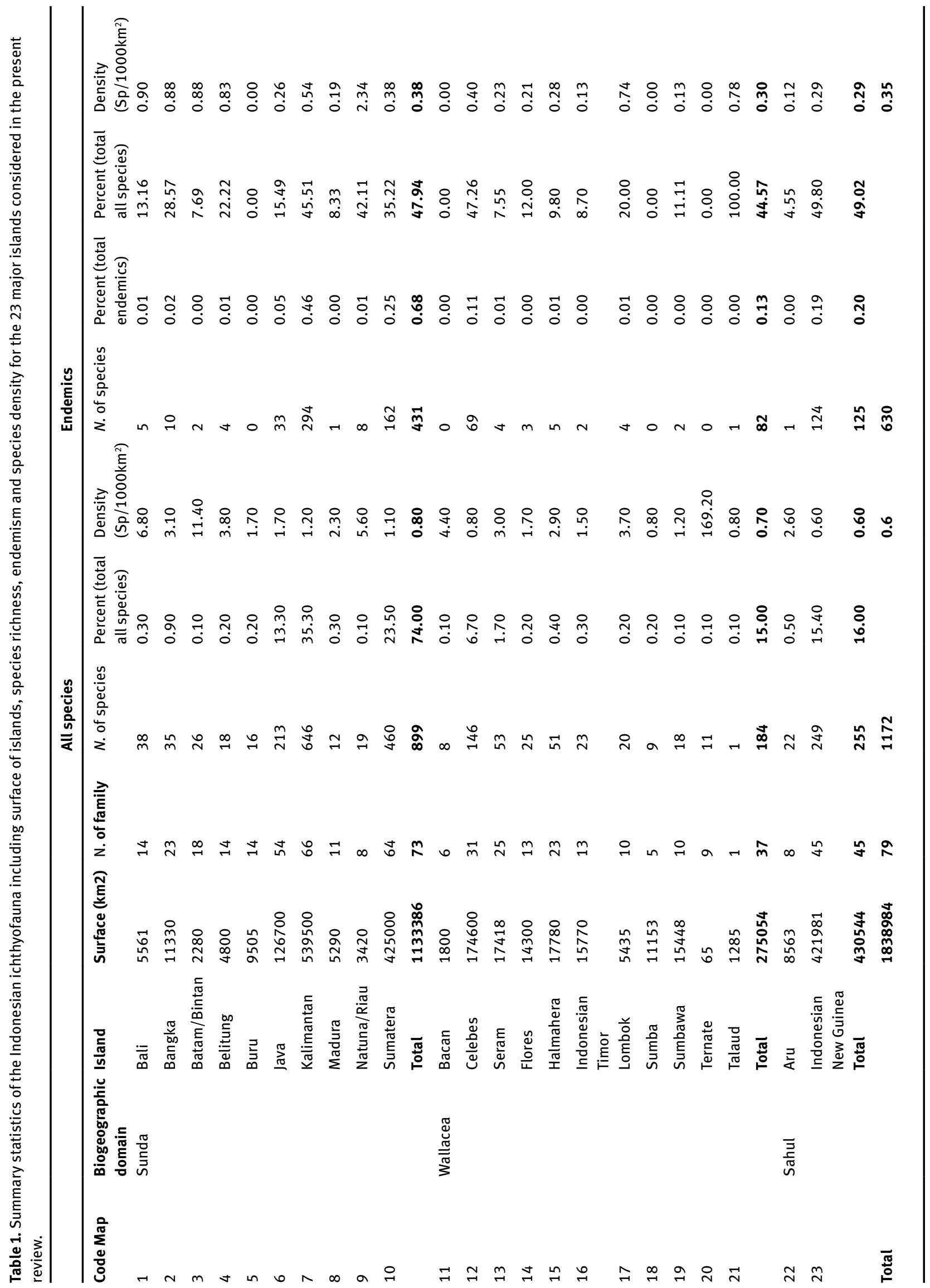


Fig. 2B) while Wallacea and Sahul are dominated by the Gobiidae (52 species) and Melanotaeniidae (47 species), respectively (Fig. 2C \& 2D). A similar pattern is observed when considering endemism, as the family Cyprinidae is also the richest family with 132 endemic species, all observed in Sundaland (Fig. 3A \& 3B). Endemism in the family Osphronemidae is also among the highest with 59 endemic species, all observed in Sundaland. The Melanotaeniidae is the third family with 45 endemic species and exhibits the highest level of endemism, as 45 of the 47 species are endemic of Sahul. The family ranking according to the number of endemic species follows the same pattern as for the whole ichthyofauna in Wallacea with Gobiidae, Adrianichthyidae and Telmatherinidae being the richest families with 23,18 and 17 endemic species, respectively. The same pattern applies in Sahul with Melanotaeniidae, Eleotridae and Gobiidae being the most diverse with 45, 20 and 14 endemic species, respectively.

The earliest descriptions of SEA native species were done in 1758 by Linnaeus (e.g. Clarias batrachus). The rate of species description in SEA has been low until the 1850's with 204 species described between 1848 and 1857 (Fig. 4A). Since then, the rate of species description per decade has undergone two additional peaks: (1) the first between 1898 and 1917 (i.e. development of the Dutch colonies in SEA) with numerous description from
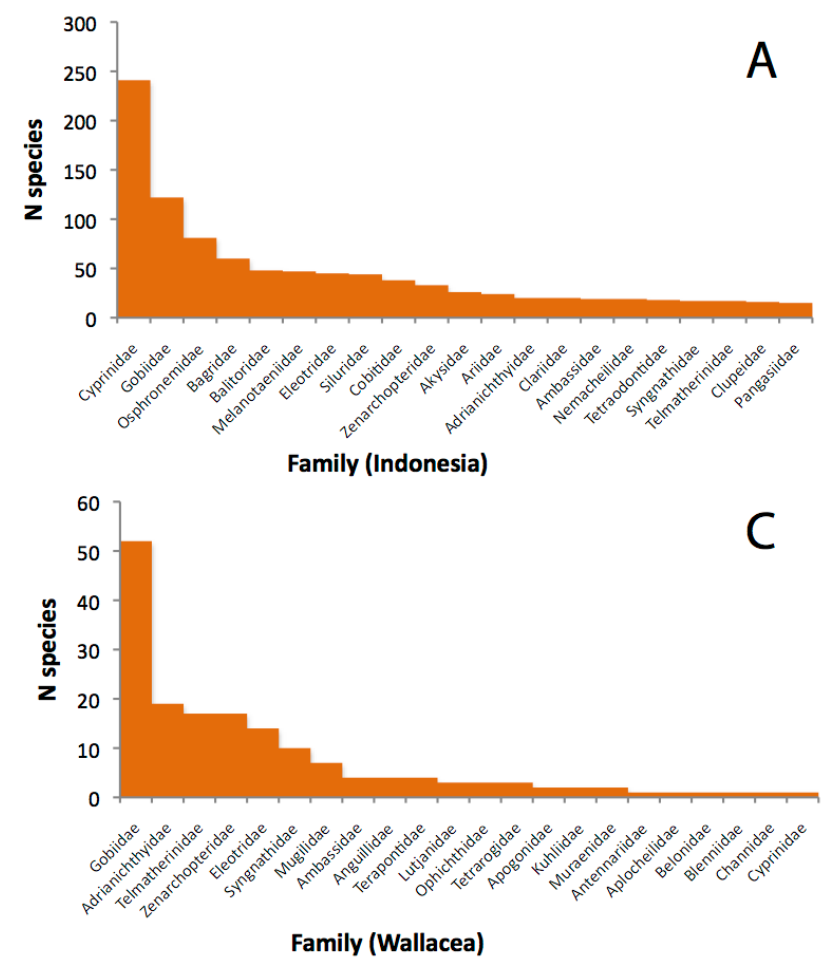

Wallacea and Sahul, (2) the second since 1978 until now corresponding to the modern ichthyological exploration of the Indonesian freshwaters and the development of comprehensive systematic studies of SEA freshwater fishes. Many species in Sahul have been described during the modern period (e.g. Melanotaenia spp.; Fig. 5) and are to be attributed to the development of transportation systems and eased access in the eastern part of Indonesia (e.g. Indonesian Papua). Many species, however, have been described from Sundaland during the same period and correspond to the reappraisal of diversity in complex groups of closely related species (e.g. Rasbora spp., Betta spp., Parosphronemus spp., Clarias spp., Ompok spp., Osteochilus spp.; Fig. 5) as a consequence of an increased taxonomic and systematic knowledge of the Indonesian ichthyofauna (e.g. Rasbora) as well as the use of integrative taxonomy including molecular phylogenetics (e.g. Clarias, Pangasius). The impact of the modern ichtyological exploration of Indonesian waters is also reflected by the distribution of the number of description of endemic species per decades as 295 of the 631 endemic species have been described since 1978, that is 47 percent of the Indonesian endemic species (Fig. 4B).

The majority of the species described or recorded in Indonesia are less than $15 \mathrm{~cm}$ with 238 species of less than $5 \mathrm{~cm}, 322$ between 5 and $10 \mathrm{~cm}$ and 166 between 10 and $15 \mathrm{~cm}$ (Fig. 4C; Fig. 5). Most of the
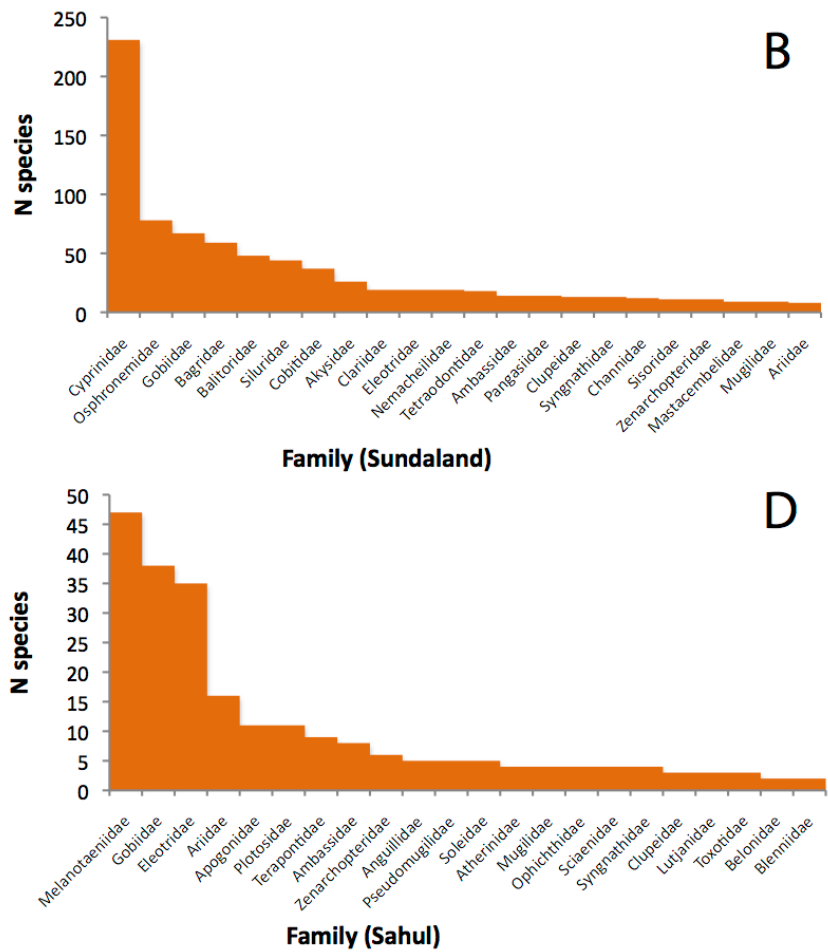

Figure 2. Ranking of the freshwater fish families according to their species richness (Appendix). A, Indonesia; B, Sundaland; C, Wallacea; D, Sahul. 

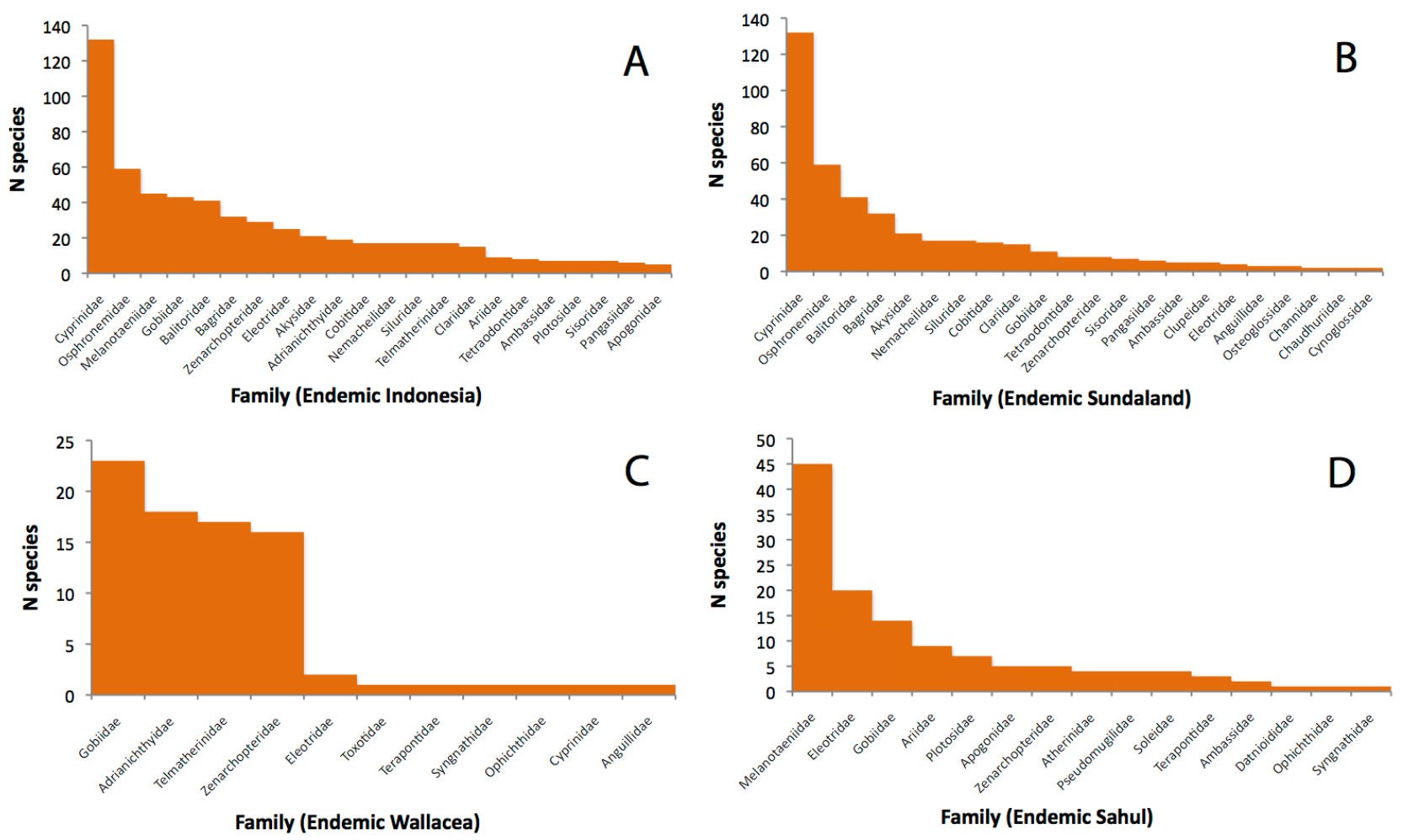

Figure 3. Ranking of the freshwater fish families according to their number of endemic species (Appendix). A, Indonesia; B, Sundaland; C, Wallacea; D, Sahul.

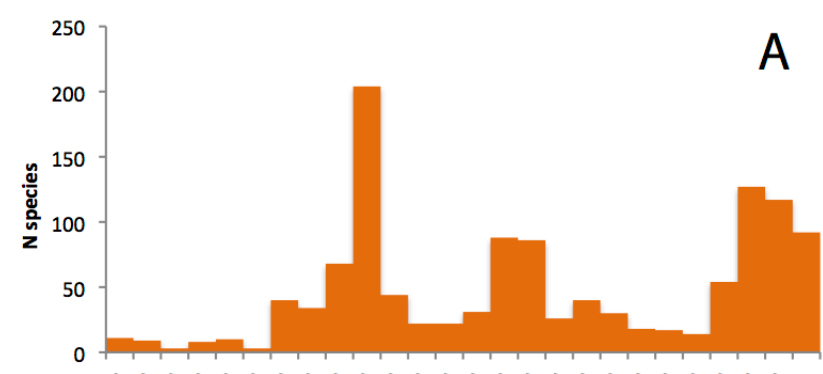

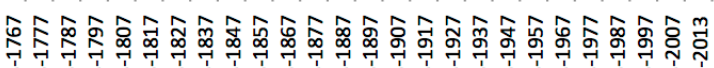

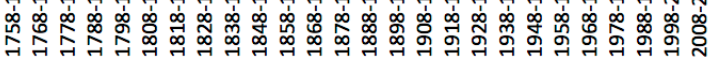

All species

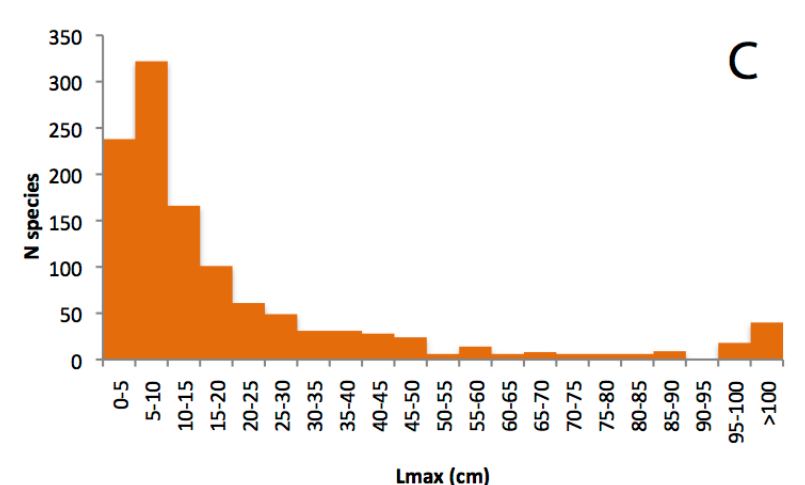

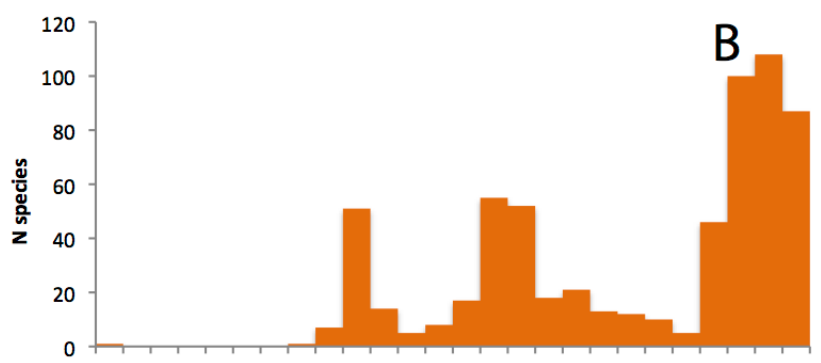

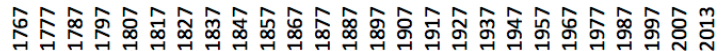

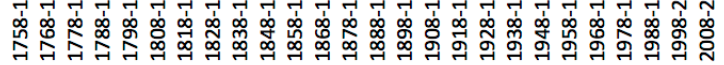

Endemics

Figure 4. Number of species description per decade and distribution of maximum length classes for the native freshwater fish species of Indonesia. A, all species; B, endemic species; $C$, distribution of maximal length per $5 \mathrm{~cm}$ classes. 

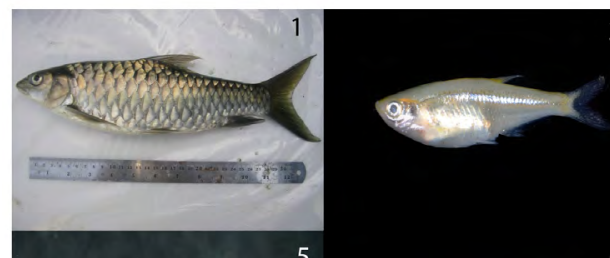

2

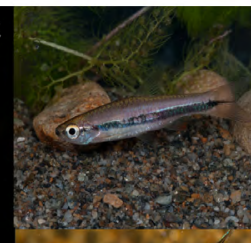

6
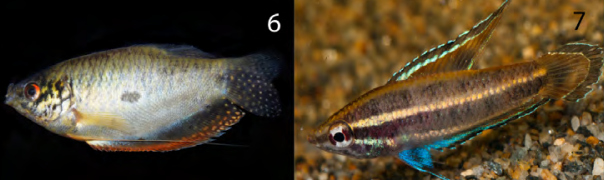

3
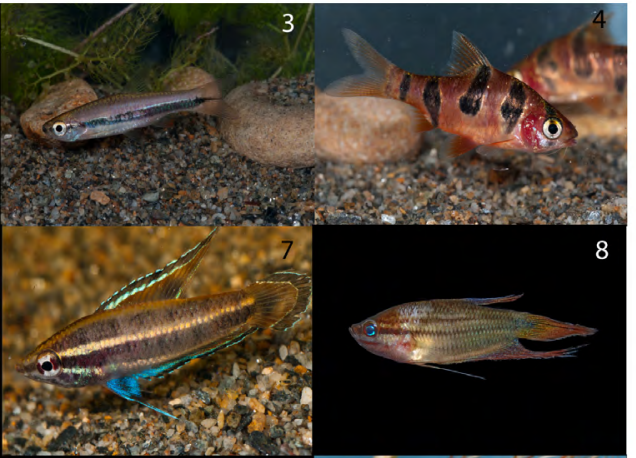

10
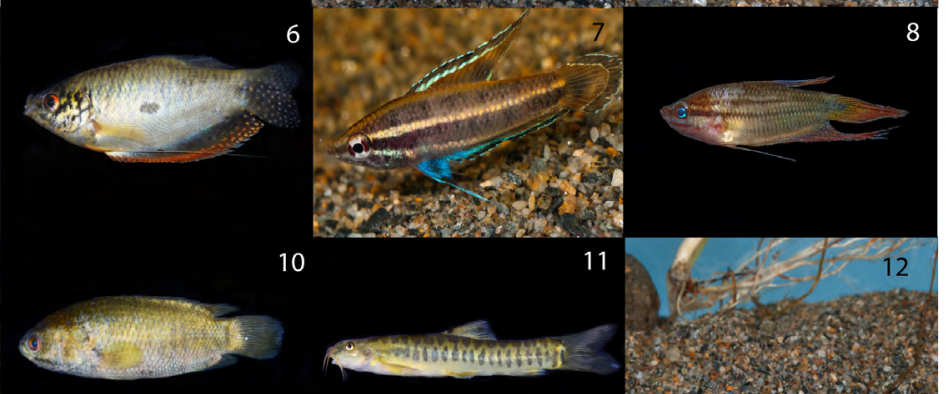

apowavos

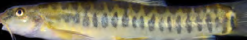

11

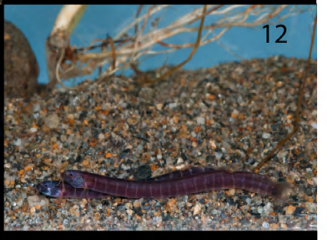

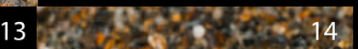
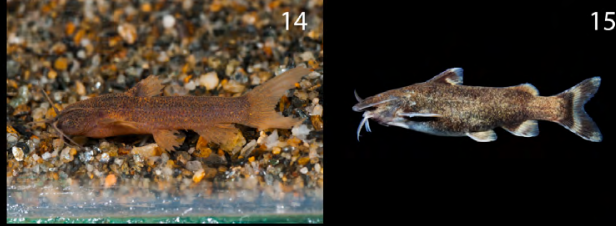

15

16

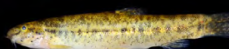

pixton,

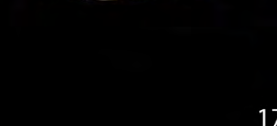

17

18
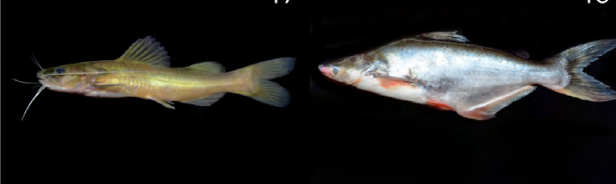

21

22

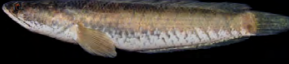

19

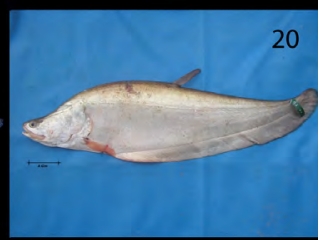

23

24
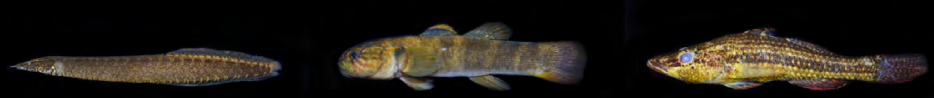

sastere

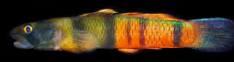

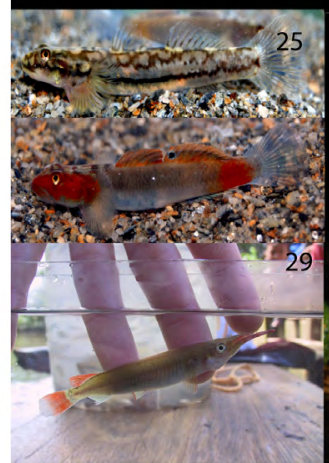

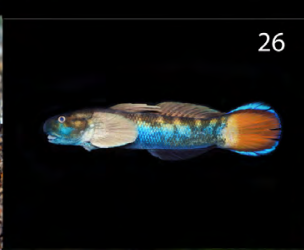

30
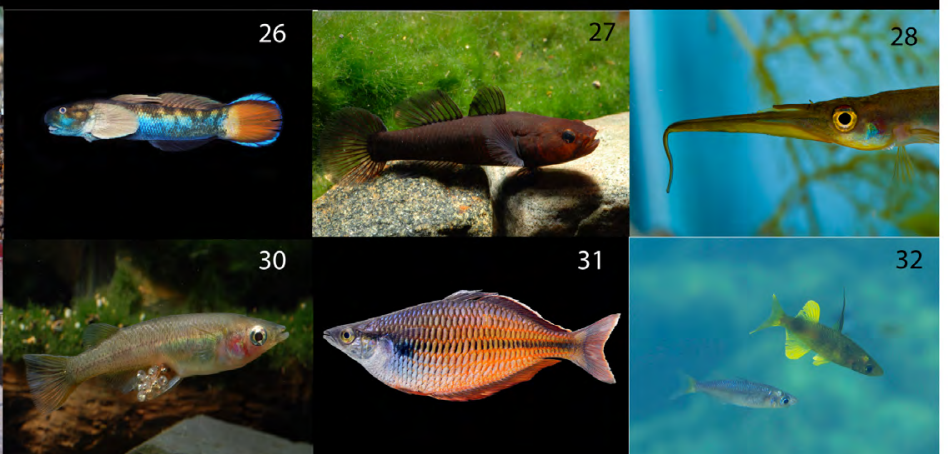

31

32

Figure 5. Selected photographs of some emblematic species and lineages of the Indonesian ichtyofauna. 1, Tor sp. (Picture A. Wibowo); 2, Parachelo oxygastroides (Picture N. Hubert); 3, Rasbora patrickyapi (Picture L. Rüber); 4, Desmopuntius rhomboocellatus (Picture L. Rüber); 5, Paedocypris cf. carbunculus (Picture L. Rüber); 6, Trichopodus trichopterus (Picture N. Hubert); 7, Parosphromenus opallios (Picture L. Rüber); 8, Trichopsis vittata (Picture N. Hubert); 9, Betta hendra (Picture L. Rüber); 10, Anabas testudineus (Picture N. Hubert); 11, Nemacheilus fasciatus (Picture N. Hubert); 12, Pangio pulla (Picture L. Rüber); 13, Lepidocephalichthys hasselti (Picture N. Hubert); 14, Parakysis notialis (Picture ); 15, Glyptothorax platypogon (Picture N. Hubert); 16, Clarias batrachus (Picture N. Hubert); 17, Hemibagrus nemurus (Picture N. Hubert); 18, Pangasianodon hypophthalmus (Picture N. Hubert); 19, Channa striata (Picture N. Hubert); 20, Chitala lopis (Picture A. Wibowo); 21, Macrognathus aculeatus (Picture N. Hubert); 22, Belobranchus segura (Picture N. Hubert); 23, Butis amboinensis (Picture N. Hubert); 24, Sicyopus zosterophorum (Picture N. Hubert); 25, Lentipes mekongaensis (Picture R. Hadiaty); 26, Sicyopterus lagocephalus (Picture N. Hubert); 27, Mugilogobius hitam (Picture F. Herder); 28, Hemirhamphodon pogonognathus (Picture L. Rüber); 29, Nomorhamphus rex (Picture F. Herder); 30, Oryzias eversi (Picture F. Herder); 31, Melanotaenia fascinensis (Picture L. Pouyaud); 32, Telmatherina antoniae (Picture F. Herder). 
descriptions during the modern period correspond to small sized species, what highlight the difficulties associated with the characterization and delineation of lineages for those small sized species [e.g. 13,41-45]. The distribution of the number of species description per decade highlights that taxonomic studies have been fragmented during the pre-modern period but also that despite two centuries and a half of ichthyological inventories; many species are still described regularly throughout Indonesia, not only from the most remote rivers and lakes of Wallacea and Sahul.

\section{Integrative taxonomy in Indone- sian fishes: species discovery and systematic knowledge}

\subsection{The Sundaland ichthyofauna}

Sundaland is the western most biogeographic domain of the archipelago and also the most speciose either considering the number of widespread or endemic species (Table 1). Sundaland is also the only domain where families of primary freshwater fishes are dominant in term of species richness (e.g. Cyprinidae, Osphronemidae, Bagridae, Balitoridae, Siluridae, Cobitidae; Fig. 5). This relative importance is largely determined by the palaeoecological history of Sundaland and past connections with centers of diversification and refuges for primary freshwater fishes (e.g. Cypriniformes, Siluriformes; Fig. 5). For instance, Kalimantan has played the role of a center of diversification for several lineages of primary freshwater fishes such as the Balitoridae (e.g. Gastromyzon, Homaloptera), Cobitidae (e.g. Pangio), Cyprinidae (e.g. Eirmotus, Lobocheilos, Osteochilus, Desmopuntius, Rasbora), Osphronemidae (e.g. Betta, Parosphronemus), Akysidae (e.g.Acrochordonichthys, Parakysis, Pseudobagarius), Bagridae (e.g. Pseudomystus) and Sisoridae (Glyptothorax) fostering the settlement of high level of endemism for those groups. De Bruyn and colleagues [35], for instance, have demonstrated that Borneo's diversity (including Kalimantan in Indonesia and Sabah and Sarawak provinces in Malaysia) resulted not only from the accumulation of immigrants but also from in situ diversification that further enabled the dispersal of species to other islands in Sundaland including Java and Sumatra. Dispersal among Sundaland islands has been made possible by eustatic changes during glacial times through the Pleistocene that created connections between the islands of Sundaland but also with the continent $[9,10,34,46]$.
Recent molecular phylogenetic studies have provided important insight into intra- and interrelationships of the most speciose families. With more than 3200 species, the Cypriniformes are the most species rich lineage. The last few years have seen an increase in molecular phylogenetic studies addressing Cypriniform intrarelationships [e.g. 47] or focusing on different Cypriniform subgroups. Cypriniformes is divided into the two superfamilies Cobitoidea and Cyprinoidea and a total of families ranging from 11 [12] to 13 [47] depending on the authors. The Cobitoidea comprise the families Catostomidae, Gyrinocheilidae, Vaillantellidae, Cobitidae, Ellopostomatidae, Barbuccidae, Balitoridae, Serpenticobitidae, Nemacheilidae (Fig. 5). With the exception of the Catostomidae and the Serpenticobitidae, all these families are found in Sundaland (Appendix). On the other hand the Cyprinoidea include the families Psylorhynchidae and Cyprinidae, the later one is ubiquitous in Sundaland. Several attempts to subdivide the species rich family Cyprinidae by erecting new families have been done recently [e.g.` 48,49] but these systematic rearrangements based on molecular phylogenetic studies have not been adopted by subsequent workers [e.g. 11,50].

Recent work on Cobitoidea intrarelationships [e.g. 51,52] mainly focused on the phylogenetic placement of several rare and species-poor lineages such as the Barbuccidae (one genus, two species, one of which is found in Borneo), Ellopostomatidae (one genus with two species, one of which is found in Borneo), Vaillantellidae (one genus with three species, all of which are found in Borneo), and Gyrinocheilidae (one genus with three species; one species Gyrinocheilus pustulosus occurs in Borneo). Cobitidae intrarelationships were addressed a few years ago by Slechtova and colleagues [53,54] who explored the genera relationships inside the family including several well-known lineages from Sundaland such as Acanthopsis, Kottelatlimia, Lepidocephalichthys, Pangio or the monotypic genus Chromobotia who's sole representative the clown loach (C. macracanthus) from Borneo and Sumatra is an important ornamental fish species. The largest genus within the southern lineages of Cobitidae is Pangio with currently 32 recognized species including several well-known and valued ornamental species, such as the kuhli loaches. Bohlen and colleagues [55] explored recently the phylogenetic relationships among Pangio species and suggested the presence of several cryptic species within the genus.

The phylogenetic intra- and interrelationships of the family Cyprinidae have been certainly the most studied, with several studies looking at the evolution of the entire family or focusing on a single subfamily 
[43,56-62]. The Cyprinidae subfamily Danioninae, a large group composed predominantly of South and Southeast Asian minnows, is among the best known subfamily and harbors several genera that are very popular in the ornamental fish trade (e.g. Boraras, Danio, Rasbora, Trigonostigma, Sundadanio). Their intra-relationships have also been largely explored recently [43,62-64]. This subfamily harbors many miniature taxa including highly developmentally truncated ones [62], some of which have only been described very recently. For example, the genus Paedocypris that includes the world's smallest fish species (Paedocypris progenetica), was only described in 2006 [42]. Paedocypris currently includes three endemic species of the highly stenotopic peat swamp forest found in Peninsular Malaysia, Sumatra and Borneo. The genus Fangfangia, also a peat swamp forest endemic, contains only one species (Fangfangia spinocleitralis) that is found in Central Kalimantan, Borneo [44]. Miniaturized taxa are often difficult to place phylogenetically - and Paedocypris is no exception - due to the frequently observed trend towards reduction and simplification of various structures and organs [62]. The phylogenetic placement of Paedocypris in the family Cyprinidae has been subject to intense debate during the last years [e.g. 49,50,62-64] and results highlighted that more molecular phylogenetic studies are needed to provide a robust phylogenetic framework to better understand Cyprinidae diversity.

Labyrinth fishes or Anabantoidei constitute another major component of the Sundaland ichthyofauna. They exhibit an Afro-Asian distribution and are arranged into three families: Osphronemidae (over 120 species in three subfamilies Osphroneminae, Macropodisnae, and Luciocephalinae), Helostomatidae (one species, Kissing Gourami), and Anabantidae (around 30 species). While the former two families are restricted to Asia, the Anabantidae are found in both Africa and Asia with the widespread Anabas testudineus, the climbing perch being the sole Asian member of this family. Although, a comparatively small group, Anabantidae exhibit a striking variation in size, ranging from dwarfed forms such as Parosphromenus ornaticauda, with $19 \mathrm{~mm}$ standard length, to large forms such as the giant goramies of the genus Osphronemus, with up to $70 \mathrm{~cm}$ standard length. A number of species play an important role as food fishes and are widely used in aquaculture (Osphronemus, Anabas, Helostoma; see elsewhere in the text), whereas others are important and highly colorful aquarium fishes such as the fighting fishes (Betta spp.), and the licorice gouramis (Parosphromenus spp.). Labyrinth fishes show an astonishing diversity in breeding behavior that is rarely found in any other fish group. Reproductive modes range from free-spawning tactics without parental care to substrate spawning, submerged plant nest building, bubble nesting, and mouth-brooding with parental care. While the most comprehensive molecular phylogenetic framework for labyrinth fishes has been provided by Rüber and colleagues [65], molecular studies focusing on diversity patterns at the genus level or phylogeographic studies are still scarce for this group [but see 66].

Recent studies on the phylogeography of Sundaland fishes based on mitochondrial genes confirmed that the evolutionary history of Sundaland fishes was marked by the landmass dynamics during the Pleistocene resulting from the eustatic fluctuations. Nguyen and colleagues [67], for example, have highlighted that species of the cyprinid genus Tor widely distributed in SEA, showed contrasting patterns of diversity depending on the proximity to Sundaland as species widely distributed in Sundaland exhibits high levels of cryptic diversity and sister-lineages with trans-island relationships. In Tor douronensis, in particular, they observed four mitochondrial lineages with allopatric distributions across Peninsular Malaysia, Borneo and Sumatra. Along the same line, De Bruyn and colleagues [34] evidenced that species boundaries in the genus Dermogenys, Nomorhamphus and Hemirhamphodon derived from mitochondrial sequences were matching palaeodrainage boundaries during periods of low sea levels but poorly matched current islands boundaries. The authors also detected cryptic diversity for widespread species with insular endemic mitochondrial lineages. The study by Pouyaud and colleagues [68] on the catfish genus Clarias yielded similar results as an important level of cryptic diversity was detected for the widespread Clarias species in Sundaland (e.g. C. olivaceus, C. meladerma, C. punctatus and $C$. nieuhofii) with range distribution of the mitochondrial lineages rather matching palaeodrainages than modern islands boundaries.

\subsection{The Wallacea ichthyofauna}

Located east of Wallace's line, Sulawesi's freshwater fauna sharply differs from that of Sundaland, including the nearby Borneo. Besides of euryhyaline lineages, or such with larval stages drifting across brackish or marine barriers, Sulawesi's inland waters are well known for their landlocked radiations of invertebrates and fishes [reviewed in 69]. The most spectacular and diverse of these radiations occurs in the ancient lakes of Central Sulawesi, namely the Malili Lakes system, and Lake Poso. Besides of lacustrine radiations of gastropods, crabs, shrimps, and other invertebrates, the ecosystems of these isolated, deep, and long-term stable freshwater lakes are 
characterized by fish species flocks. The most spectacular radiation in Sulawesi is observed in the sailfin silversides (Telmatherinidae; Fig. 5) from the interconnected Malili Lakes, including the $590 \mathrm{~m}$ deep graben-lake Matano [41,70-72]. These small, Atheriniformes fishes with colorful male ornamentation are closely related to New Guinea's and Australia's rainbowfishes, and serve as model system for the study of speciation mechanisms [summarized in 73], and the maintenance of color polymorphisms in nature [e.g. 74,75].

Mitochondrial sequencing was performed as one of the initial steps for estimating sailfin silverside species diversity [41,76]. In agreement with morphology and nuclear data, mitochondrial markers resolved major lineages of the radiation [41], and provided valuable insights into the phylogenetic history, the origin, and time estimates of its divergence [77]. Mitochondrial sequences, however, are less suited for discriminating morphospecies within the major lineages of this radiation [41,72]. For instance, introgressive hybridization between stream- and lake-dwelling sailfin silversides [78] has lead to severe confusion in previous studies relying solely on mitochondrial markers for species delineation [e.g. 73,76,79].

The absence of species-level resolution in mitochondrial markers is not unexpected in evolving radiations, particularly when ecological speciation takes place in the absence of geographical barriers, as observed in the endemic lacustrine species of Lake Matano [80,81]. Introgressive hybridization among closely related species is also known to blur phylogenetic signal, particularly for maternally inherited mitochondrial markers. Mitochondrial-based studies of species diversity in lake ecosystems, however, provided valuable information. In some of the invertebrate radiations of the Sulawesi Lakes, such as Atyiidae shrimps, or Geocarcinucidae crabs, mitochondrial sequences have been generally very well suited for discriminating species.

In the case of Sulawesi's ricefish radiation, which comprises riverine as well as lacustrine species (Fig. 5), mitochondrial sequences contributed significantly to species discovery and improved our current understanding of their evolutionary history [82-85]. Nevertheless, a few species flocks that evolved in lacustrine environment, as in L. Towuti for instance, display some intricate patterns of shared polymorphism [83].

\subsection{The Sahul ichthyofauna}

Located east of Lyddeker's line, the ichthyofauna of Sahul shares similar characteristics with the ichthyofauna of Wallacea. While contributing by only
16 percent to the Indonesian ichthyodiversity and 20 percents to the total number of endemic species in the country, some lineages (e.g. Melanotaenia, Mogurnda) exhibit up to 100 percent of endemism (Table 1). The rainbowfishes belonging to the genus Melanotaenia (Fig. 5) represent the most speciose group of freshwater fishes in Indonesian Papua with 33 species that are all endemic to the region. Inside Indonesian Papua in particular, Allen [86] initially suggested that the western part of the island, also known as the Bird's Head peninsula, might be a hotspot of rainbowfish diversity according to the initial exploration of the area that led to the description of several new species. The subsequent ichthyological exploration of the area confirmed this hypothesis through the description of several additional species of Melanotaenia based on a screening of morphological characters [87-89] and leading the citation of 13 species from the Bird's Head.

The large-scale and standardized sequencing of the COI gene for rainbowfish species from the genus Melanotaenia with the aim to re-estimate the diversity in Indonesian Papua provided an unprecedented level of species discovery in the group [13]. Kadarusman and colleagues [13] have detected 30 mitochondrial lineages among the 13 nominal species of Melanotaenia in the Bird's head, all being distributed in allopatry and restricted to a single watershed. This cryptic diversity has been further confirmed by the high levels of genetic differentiation based on microsatellite genotyping and the discovery of several diagnostic morphological characters [90]. By doubling the number of known species in the area, Kadarusman and colleagues [13] and Nugraha and colleagues [90] highlighted that the diversity of the family was largely underestimated and pinpointed the urgent need to re-appraise the diversity of this group in other region of Indonesian Papua for national conservation plans.

The use of mitochondrial DNA sequencing lead to spectacular levels of species discovery in Indonesian Papua because allopatric speciation in fragmented landscapes has been the major driver of the rainbowfish diversification [13]. Hybridization is known to occur easily among Melanotaenia species and inter-generic hybrids have even been observed [86], a result that was confirmed although by Kadarusman and colleagues as introgressive hybridization between Melanotaenia and Glossolepis species was observed in one case. Phylogenetic inferences based on mitochondrial DNA also helped estimating the time frame of the Melanotaenia diversification and confirmed the influence of the complex geological history of the Papua island in shaping the current distribution of the family $[13,91]$. 
Worth mentioning, a similar pattern of endemism is observed in the genus Mogurnda encompassing nine species, all being endemic of Indonesian Papua. The genus Mogurnda is the sole genus of the family Eleotridae to exhibit 100 percent of endemism. The descriptions of Mogurnda species have all been done during the 1990's by Allen and colleagues [92-95] and a recent survey of mitochondrial diversity in closely related Australian Mogurnda species revealed that cryptic diversity was prevalent in the genus and the actual diversity to be as much as twice the extent number of nominal species today [96].

\subsection{Euryhaline and diadromous lineages with regional distribution}

Euryhaline and amphidromous species represent an important contribution to the Indonesian ichthyofauna, sometimes in a high proportion as in Wallacea and Sahul (e.g.Gobiidae, Eleotridae, Ariidae, Apogonidae, Plotosidae, Terapontidae, Ambassidae, Mugilidae, Anguillidae). This relative importance is largely determined by the palaeoecological history of each biogeographic domain in Indonesia and past connectivity ( $c f$. section related to Sundaland). Islands of Wallacea and Sahul have been isolated from regional pools of primary freshwater fishes by contrast with Sundaland that has been repeatedly connected to the SEA continent. Several insular radiations happened in both Wallacea (e.g. Telmatherina, Oryzias, Nomorhamphus) and Sahul (e.g. Melanotaenia), however, several families including euryhaline and diadromous fishes ( $c f$. example above) constitute an important contribution to the diversity of both Wallacea and Sahul. Past connectivity among islands, however, had different consequences for those lineages. This trend is particularly evident for amphidromous species with marine larval stages enabling connectivity among populations from different islands and exhibiting highest colonization potential due to their ability to achieve largescale dispersal as a consequence of long larval survival in oceans [97,98]. As a consequence, such amphidromous lineages show more similarity in their population dynamic with coastal marine fishes whose adults are sedentary and connectivity is maintained through larval dispersal as observed in coral reef fishes [99-101]. Species richness in Indo-Pacific reef fishes exhibits a marked heterogeneity following a gradient that peaks in the Philippines and Indonesia and decreases toward the west and the east [102-106]. The origin of this gradient of diversity has been intensively debated during the last two decades as several mechanisms have been proposed to account for the settlement of this gradient including the existence of a center of overlap among distinct biogeographic domains $[29,107,108]$, the highest connectivity of the Pleistocene coral reef refuges in the Indo-Australian archipelago [109] and geometric constraints on the distribution of species richness [110,111].

With eight valid genera (Sicyopterus, Cotylopus, Smilosicyopus, Sicyopus, Akihito, Stiphodon, Lentipes and Sicydium; Fig. 5) and over 110 species [112], the amphidromous fishes of the Sicydiinae subfamily (Teleostei: Gobioidei) constitute some of the major contributors to the freshwater fish biomass in river systems of remote tropical islands [113, 114]. The first molecular phylogeny of the Sicydiinae estimated that the group emerged quite recently around 6-12 Myrs ago [115] and the ancestral area reconstruction made by Taillebois and colleagues [112] suggests that Sicydiinae might have emerged within the Indonesian shelf that has probably been a key area in the diversification of some clades such as Sicyopus and the Cotylopus/Smilosicyopus group [116]. In Indonesia, nearly 11 type localities of Sicydiinae are found among the 26 species reported in Indonesia, that is $43 \%$ of the Sicydiinae species cited in the country. The systematic of this group, however, is still largely controversial and calls for a finer assessment of the family diversity in Indonesia. The recent description of four new Lentipes and Sicyopus species confirms that the Sicydiinae fauna is still poorly known in Indonesia [117,118]. The molecular phylogeny of the group, however, evidenced that molecular lineages generally match species boundaries and confirmed that Sicydiinae inventories may benefit from a standardized sequencing for species delineation and assignment [115].

\section{Molecular diagnostic, DNA barcoding and management of ich- thyological resources}

\subsection{Fisheries management}

Most of the large rivers in Sundaland host inland fisheries that supply freshwater fish markets mainly dedicated to local consumption as in central Sumatra (e.g. Musi river) [119] and west Kalimantan (e.g. Kapuas river) [120]. Some fisheries are specialized on species with high economic and socio-cultural values such as the featherbacks (Chitala spp.) or Mahseer (Tor spp.) in Sundaland [119,120].

The Chitala spp. belong to the family Notopteridae that exhibits only few species distributed mainly in SEA 
(i.e. 7 species, all cited from Indonesia) and 3 species in Africa [12]. Family's age estimates based on complete mitochondrial genomes, however, date the origin of the family and the separation between African and Asian lineages during the early cretaceous around $160-180$ Myrs ago and around 130 - 150 Myrs ago, respectively [121]. Thus, aside of high socio-economical interest, featherback are also of high patrimonial importance in SEA. The giant featherback (Fig. 5) is very popular in Sumatra owing to the large size it can achieve (i.e. $1.5 \mathrm{~m}$ ) and its nutritional qualities [122] that rank it as one of the most sought fish for consumption in the area [119] and the most expansive fish species in the central Sumatra fish markets [119,122]. As a consequence, the fishing pressure has grown dramatically during the last decades and giant featherback fisheries have experience a stunning decline in productivity as exemplified in the Kampar river where the annual production dropped from 50.2 tons in 2003 down to 7.6 tons in 2007 [123]. Sequencing of mitochondrial genes, however, indicated that at least four distinct cryptic mitochondrial lineages may be observed in the populations of the giant featherback in Sumatra [119]. A distinct stock, for instance, has been evidenced from the Kampar river and distribution of nucleotidic diversity at mitochondrial sequences highlights that populations of the giant featherback are highly structured spatially in Sumatra suggesting that local scale is more appropriate for fisheries management than regional plans.

Another iconic group of species of the Sundaland inland fisheries is the mahseer (Tor spp.; Fig. 5), an economically important genus of Cyprinidae. Present from India to Indonesia and Malaysia, Tor spp. have played a great role in local fisheries in most of the countries where they occur [e.g. 120,124]. Tor spp. are amongst the most popular Indonesian freshwater fishes both for their table and cultural values owing to their large size (i.e. $1 \mathrm{~m}$ ) and nutritional qualities. The market price for Mahseer in Indonesia and Malaysia is amongst the highest ranging from 16 to 60 US\$ per kg [120], however, its abundance has dwindled substantially in their natural habitat since the early 90's $[10,125]$. In addition, most Tor spp. are rheophilic species know to migrate downstream during the onset of the raining seasons for spawning [12] and as such have been largely affected by the development of dams. Furthermore, Mahseer's controlled breeding is still poorly developed mainly due to the difficulties to induce maturation and ovulation by using hormonal treatments [126]. The dynamic of migration and life history traits are still poorly known in Indonesian populations of Mahseers from Sumatra and Kalimantan, however, cryptic diversity and population structure among rivers have been previously described based on mitochondrial sequences [67,125].

Understanding migration of early life stages is of utmost importance for fisheries management, a knowledge that is critically needed when considering amphidromous species including a marine larval stage such as the Sicydiinae (Gobiidae). Due to their marine larval stage (cf. previous section), they constitute the most important contributor to the biomass in river systems of remote tropical islands [113]. The biomass of larvae migrating upstream is so important during some periods of the year that they represent an important source of food for local human populations in some archipelagos [127], particularly in the Philippines and Indonesia [128]. The naturally unstable and ephemeral characteristics of these tropical systems, which have become even more so in recent years as a result of anthropogenic perturbations, however, make the Sicydiinae particularly vulnerable [129]. Thus, harvesting this resource is highly unsustainable, on account of the complexity of the species life cycle. For such species, estimating the larval biomass per species during those migrations is tightly linked to the ability to identify larvae. Nevertheless, given their high diversity and dramatic phenotypic changes during development, fish larvae identification is not an easy task and Sicydiinae and not an exception to this [24]. The first molecular phylogeny of the group suggested that the use of mitochondrial sequences for species identification may be possible since no mismatch between species boundaries and molecular lineages was detected [115].

\subsection{Ornamental trade}

Over the last decades, the international tradein ornamental fishes has grown rapidly from small export fisheries in the Central Amazon and SEA to an industry that involves most tropical regions and generates some 200-300 millions USD annually. The value of the ornamental fish exports has been reported to increase by $14 \%$ per year between 1985 and 1996 [130,131]. The increase of the international trade of ornamental fishes over the years poses a great challenge to national authorities in SEA since this market is still depending on capture in the wild for many species $[132,133]$. In 2003, Indonesia ranked as the second highest exporting country of ornamental fishes by contributing to nearly $7 \%$ of the global trade [134].

Blackwaters associated with peat swamp forests in Sundaland, for example, are home to many species interesting the international ornamental fish trade including Betta spp., Parosphronemus spp., Sphaerichthys spp., Rasbora spp. and Boraras spp. (Fig. 5) among the most 
prominent examples [135]. Blackwater swamps, however, are experiencing an alarming rate of land conversion. Forest loss in the lowlands of Sumatra and Kalimantan, the two Indonesian provinces containing the largest areas of peat swamp forest and accounting for more than $70 \%$ of forest clearing in the country from 1990-2005, resulted in a staggering $41 \%$ loss in total area in just 15 years [136,137]. Thus, the need to improve our taxonomic knowledge on endangered species either collected in the wild or reared and bred captive for ornamental purposes is crucial in Indonesia.

Over the past few decades, the Asian arowana Scleropages formosus has acquired an emblematic status in most Asian countries as a very popular but extremely expensive aquarium fish, which has led to its overexploitation and its inclusion in the CITES list of species threatened with extinction [138]. In a phylogenetic analysis based on the sequencing of the mitochondrial cytochrome b gene and supported by several diagnostic morphological characters, Pouyaud and colleagues [139] demonstrated that the four different color varieties of S. formosus were distinct species. Those included the "Silver" described as Scleropages macrocephalus, the "Golden" belonging to $S$. aureus, the "Red" identified as S. legendrei, and the "Green" restricted to S. formosus. The authors also proposed to reconsider the status of $S$. aureus and S. legendrei as critically endangered species because both species previously considered as color varieties of $S$. formosus were in fact exhibiting highly confined geographic distribution very dependent on the nature and quality of the habitat (e.g. peatswamps), and therefore threatened of extinction due to habitat loss and overexploitation for ornamental purposes [139]. The capture of specimen in the wild for the international ornamental fish trade also poses serious and immediate threats to other Indonesian fishes not associated with the peat swamps. The clown loach (Chromobotia macracanthus), for instance, is another prime example of an iconic species of the ornamental trade whose captive breeding has been tuned only recently [140] and its marketing has been entirely sustained during decades from captures in the wild.

The Gobiidae subfamily Sicydiinae also hosts several important species in the international ornamental trade. Some examples are given in Australia [141,142] where five Stiphodon species were recently discovered in small fast-flowing rivers. These species are vulnerable to overharvesting for the aquarium trade as a result of their colorful appearance, particularly in male, and interesting behaviors [113]. Given the small population size of these species and the proximity of these populations to the regional main town of Cairns, it was recommended to review the protective status for all Sicydiinae gobies of the country as the interest in collecting Stiphodon species is likely to be high for native fish hobbyists [141].

Stiphodon spp. are easy to collect and are accessible at low altitude in small streams. As a consequence, the Opal cling goby, Stiphodon semoni, widespread in Indonesia, has recently been listed in Australia under the Environment Protection and Biodiversity Conservation Act. A recent paper reviewing the Stiphodon species in Sumatra, and describing one as new [143], used more than half of the specimens of all three Stiphodon species examined from ornamental traders in Singapore. Stiphodon gobies are often sold commercially as ornamental fish. These three species (S. ornatus, S. semoni and S. maculidorsalis) are common and found in many pet shops often selling them on the Internet, even if the later is supposed to be endemic to Sumatra. The western slope of Sumatra is believed to be the main source of Stiphodon for the ornamental trade. To date, the large-scale captive breeding of Stiphodon species is still not tuned due to difficulty in feeding their small larvae, due to their amphidromy and long pelagic larval duration [144]. Therefore, all Stiphodon species available in the ornamental market are collected from the wild. The same constraints apply to other Sicydiinae such as Sicyopterus, Lentipes and Sicyopus that are occasionally available in the ornamental market.

\subsection{Aquaculture}

Freshwater fish farming, which represents $60 \%$ of aquaculture production in Indonesia, is an ancient and traditional production that is essential for the country's food security. The Indonesian ichthyofauna has several iconic species in the traditional fish farming and the giant goramy (Osphronemus goramy) is one of the most popular species in Sundaland owing to its table values [10]. The giant goramy (Fig. 5) is an omnivorous-phytophagous species fed in captivity with a variety of cultivated plants. Its traditional rearing may be considered as a prime example of integrated production system in agricultural landscapes as it generally occurs in ponds associated with plantation of cassava and papaya whose leaves are used directly for feeding adults [145].

Java is the cradle of the traditional rearing of the giant goramy as Javanese and Sundanese peoples peddled the rearing of this species throughout the history of their settlements in Sundaland and later fostered the spread of its aquaculture in the country. Huet [146], for instance, already mentioned the rearing of the giant goramy in Indonesia as one of the most important freshwater 
aquaculture in the 50's. More recently, considering the high commercial value and growing market demand for this species, fish farmers have intensified the breeding over the past few years and new goramy's farms have developed in several areas in Indonesia, particularly in central Java that is currently the main source of juveniles in Sundaland. As a consequence, the giant goramy is currently being translocated in many islands throughout the country.

The genus Osphonemus encompasses four nominal species among which, three are cited from Indonesia but only $O$. goramy has been reported from Java, Sumatra and Kalimantan (Table 1). Owing to its early history of domestication in Sundaland, however, nearly thirteen cultivated strains are currently recognized in the Javanese cultivated 0 . goramy, several of them exhibiting distinctive coloration patterns and life history traits including fecundity, mortality and growth rates (D. Caruso, pers. obs.). Setijaningsih and colleagues [147] assessed the morphometric variability of the three most common goramy strains reared in Java (i.e. Baster, Blusafir and Paris) and found no diagnostic characters distinguishing those strains other than coloration patterns. Recently, however, Nuryanto and colleagues [148] demonstrated by sequencing the mitochondrial COI gene that five of several strains in central Java (i.e. Blue Saphire, Jepang, Mutiara, Sabah and Sowang) were build upon two distinct species while actual 0 . goramy strains show little differentiation. These preliminary results highlight that the history of the domestication of the giant goramy in Sundaland has been complex, involving different species during the development of current strains and a large scale reappraisal of their biology and evolutionary relationships are urgently needed to promote a sustainable valorization of those strains.

The catfish belonging to the genera Pangasius and Clarias (Fig. 5) are other iconic species of the freshwater aquaculture production and fisheries in Indonesia but also more broadly in SEA. Despite the overexploitation of their natural populations and rearing in captivity for food consumption, the taxonomy of the genus Pangasius have been subject to various changes during the last two decades [11]. In 1991, Roberts and Vidthayanon [149] revised the family Pangasiidae and reported 21 valid species based on anatomical and morphological characters. Later, Pouyaud and colleagues reappraised the taxonomy and species richness of the family in Indonesia based on sequencing of mitochondrial DNA in combination with morphology and described five additional species [150-154]. Two species of Pangasiidae are reared in Indonesia [155], Pangasianodon hypophthalmus and Pangasius djambal, the former being exotic and the later being the most common in the country [156]. These species present distinct breeding performance (e.g. Legendre, 2008 \#2779\}, however, fertile hybrids are easily obtained in rearing condition leading to altered breeding performances and potential risks of introgression of natural populations of the native species, P. djambal [157].

\subsection{Border biosecurity and invasive species}

Invasive species may pose serious threats to native freshwater faunas, especially in insular, isolated ecosystems. There are numerous freshwater fishes that are regularly transplanted to areas outside of their original ranges as a consequence of increased human activities $[158,159]$. Invasive species have not only fostered the disruption of global patterns in freshwater fish communities [160], but some of these have turned out as invaders affecting native ichthyofaunas severely [161,162].

Given the importance of inland fisheries and traditional aquaculture in Indonesia for the economy and food safety of the country, the Indonesian government declared its concern about invasive species by the Decree of Ministry of Agriculture No. 179/1982 dated March 22, 1982. Early in the 80's, a blacklist of exotic species to be controlled at Indonesian borders was established (Serrasalmus spp., Vandellia spp., Lepisosteus spp., Silurus glanis, Esox masquinongy, Electrophorus electricus and Tetraodon spp.), mainly focusing on potentially harmful species for human populations and thereby, threatening human activities related to the harvesting of freshwater fishes. This decree, however, did not succeeded in impeding the introduction of several of those species including the alligator gar (Lepisosteus $\mathrm{sp}$.) that has been recently reported from Java and Indonesian Papua (R. Hadiaty, pers. obs.). Furthermore, little attention has been paid to other species well known for their high invasive potential such as the Tilapias (Oreochromis niloticus and O. mossambicus), the carp (Cyprinus carpio), the guppy (Poecilia reticulata), the North African catfish (Clarias gariepinus) or the Amazon sailfin catfish (Pterygoplichthys spp.) that have been introduced for aquaculture or escaped through the ornamental trade and are now widely established in Indonesia, sometimes dominating the biomass of the fish communities (R. Hadiaty, pers. obs.). More surprisingly, asiatic species have been introduced for aquaculture purposes while several candidates species belonging to the same genus were readily available in the native Indonesian ichthyofauna. The North African catfish (Clarias gariepinus), for instance, is an emblematic species of the aquaculture trade that is now cultivated in 
several countries worldwide and has become one of the most popular cultivated species in Java (i.e. Lele jumbo), for example. The genus Clarias, however, is a speciose catfish genus that has been through important taxonomic revisions recently, leading to the description of 8 new species [163-169] and raising the number of Clarias species to 13 . Worth mentioning, 11 of those 13 species are endemic of Sundaland and escapes of $C$. gariepinus from cultivated ponds are expected to have impacted their abundances in nature through competitive interactions and epizooty.

Border security officers, however, often lack taxonomic training needed to identify potential invasive species or species known to carry exotic pathogens. Collins and colleagues [170], for instance, explored the usefulness of DNA barcodes in identifying ornamental fishes obtained from the aquarium trade. They focused on cyprinids and included several popular aquarium fishes that are regularly exported from Indonesia, mostly Sumatra and Kalimantan. A total of 678 specimens, representing 45 genera and 172 cyprinid species were obtained by the authors from the aquarium trade. In addition, 562 barcode sequences from 238 species were obtained from reference libraries (GenBank/BOLD) increasing the total number of ornamental cyprinid species included in the study to 329. Many morphological similar species were well differentiated with DNA barcodes and identification success rates were generally high. The authors also observed, however, incongruence and inconsistencies in the DNA barcode data. For example, barcode sharing was observed in several groups, including taxa from Indonesia: between two Eirmotus species (E. cf. insignis and E. cf. octozona) and between two Boraras species (as Rasbora in (Collins et al. 2012), B. brigittae and B. merah). In the case of Boraras, Kottelat [11] commented on the taxonomic status of $B$. merah mentioning the potential color dichromatism in this species, but also highlighting the clear differences between the two species (shape of caudal peduncle, pigment distribution). Hence, it is likely that the supposed barcode sharing between the two species is due to misidentifying B. merah as B. brigittae.

The results of Collins and colleagues [170] also indicated a high level of unrecognized diversity. Among Indonesian taxa, for example, unrecognized diversity was found in Brevibora dorsiocellata (as Rasbora in [170]), Rasbora einthovenii, Trigonostigma heteromorpha (as Rasbora in [170]), Trigonopoma pauciperforata (as Rasbora in [170], a widespread species) and Sundadanio axelrodi. At the same time, Brevibora cheeya (Liao \& Tan, 2011) from Terengganu, Malaysia was described and recently Brevibora exilis [171] from Kalimantan Tengah, Borneo was described and both could potentially account for the "unrecognized diversity" reported by Collins and colleagues [170]. Collins and colleagues [170] highlighted that mismatch between species names applied to the specimens transiting in the international ornamental trade and taxonomic assignment based on DNA barcodes are due to either taxonomic uncertainty and/or conflict due to misidentifications. The authors hence caution the use of GenBank for identification purposes due to the potential absence of preserved voucher specimens and justified identifications and note that while BOLD data are generally better curated and with higher quality standards, they are also likely to suffer from misidentification to some degree. This case highlights the difficulties of establishing DNA barcode reference libraries when the taxonomic knowledge is rapidly evolving as exemplified with the Indonesian ichthyofauna.

The freshwaters of Sulawesi are, due to the island's location east of Wallace's line, devoid of those freshwater fish lineages making up the vast species diversity of the islands formerly connected to Sundaland [10]. In contrast, Sulawesi's inland waters, and particularly the ancient lakes, are dominated by species flocks originating from a few lineages, such as ricefishes (Oryzias, Adrianichthys), the sailfin silversides (Telmatherina, Paratherina, Tominanga) mentioned above, halfbeaks (Nomorhamphus, Dermogenys), and gobies (including flocks of Glossogobius and Mugilogobius) but rivers and streams of the island are dominated by euryhyaline species [10,172]. Alien fish species such as the snakehead Channa striata, the climbing perch Anabas testudineus, the gouramis Trichopodus pectoralis and T. trichopterus, or Tilapia (Oreochromis niloticus) are omnipresent in many areas of Sulawesi, but actual data on their occurrence or even impact to the native fauna are very restricted, and scattered in the literature.

A recent checklist of alien fish species reported 14 species occurring, and partially spreading heavily, in the Malili Lakes, Sulawesi's largest lakes system [173]. These include species commonly used for aquaculture on a local scale, such as snakeheads, gouramis, climbing perches, or walking catfishes (Clarias) from Western Indonesia or mainland Asia, but also African Tilapias, aquarium species such as the Amazon sailfin catfish (Pterygoplichthys cf. pardalis), guppy (Poecilia reticulata), African cichlids from Malawi lake (e.g. Pseudotropheus cyaneorhabdos), or common carp (Cyprinus carpio). Most of these species apparently do not pose a direct threat to the native lake species, but there is at least one exception. The artificial hybrid, the flowerhorn cichlid (also called Lou Han), bred as colorful ornamental fish in captivity, entered Lake Matano just a few years ago, but spread extremely fast 
throughout the lake. Detailed studies on its impact are pending, but the restricted data available suggest that this is an omnivorous benthic feeder, potentially interacting with the native flocks by competition and predation [173]. The even more recent introduction of the Amazon sailfin catfish highlights the multitude of artificial - and unnecessary - introductions, each of which is a largescale experiment at the cost of Sulawesi's precious ancient lakes fauna. DNA barcoding, applied to specimen samples or as "environmental barcoding" to water probes, has the potential to enhance the recognition of alien species in inland waters, once the reference libraries are made available; monitoring the spread and impact of nonnative fish species in Indonesia's lakes, rivers and streams appears timely.

Alternatively, SEA is an important source for exports internationally and several introductions of SEA fishes in temperate zones, North America for instance, with adverse effect on native ichthyofauna have been recently reported such as the striped snakehead [174]. In fact, several snakehead species (Channa spp.) have been introduced in non-native waters around the world where many developed into invasive species threatening the indigenous ichthyofauna. Channa striata is considered the most widely introduced species of snakehead. Although it is generally accepted that the native range of $C$. striata includes Borneo, Roberts [175] suggested that its presence in western Borneo might have been due to introductions. C. striata has been introduced throughout Indonesia in Sulawesi, Lesser Sundas, Moluccas and Papua [176]. There are often contradictory reports regarding the taxonomic identity of some of the introduced snakehead, for example the blotched snakehead (Channa maculata) that has been established on Oahu, Hawaii, since the late 1800s has often been misidentified as the striped snakehead ( $C$. striata).

The snakeheads (Channidae) comprise 34 species in two genera, Parachanna with 3 species in Africa and Channa with 31 species in Asia where their distribution range from Iran in the West to the Amur basin in Russia and Sundaland in the south with 12 species (Appendix). Snakeheads are highly valued as food and are used in fisheries, aquaculture, and the life-food trade and can be found in most fishmarkets in SEA. Their taxonomy and systematic has been controversial in the past, the first molecular frameworks for channid phylogenetics were published based on mitochondrial genes [177] or combining mitochondrial and nuclear genes [178]. More recently, Serrao and colleagues [179] established a Channidae DNA barcode reference library based on 250 DNA barcodes sequences representing 25 species based on a revision of available sequence data and newly generated sequences with the aim to enable identification of potential and established invasive species outside of their native range. A total of 49 discrete haplogroups were identified and multiple divergent clusters were observed within four Channa species including two species that also occur in Indonesia (C. gachua and C. striata) suggesting the potential presence of cryptic species diversity within these lineages. This knowledge is of prime importance, however, for monitoring snakehead species invasion as the family exhibits a high diversity of life history traits, particularly temperature tolerance that influences species invasive potentials [176].

\section{DNA barcoding Indonesian fresh- water fishes: perspectives}

\subsection{DNA barcode reference libraries: toward a global biodiversity information system for species identifications}

DNA barcoding is a system designed to provide accurate, fast and automatable species identification by using short and standardized gene regions as internal species tag [14]. As such, DNA barcoding is at the crossroad, while complementing, several areas of biodiversity sciences including taxonomy, phylogeny and populations genetics $[180,181]$. The initial proposal by Hebert and colleagues [15], consisted in acknowledging the effectiveness of mitochondrial COI gene in capturing species boundaries and highlighting that the discriminating power of COI gene at the species level might be used for species identification based on DNA sequences. DNA barcoding relies on the development of DNA barcode reference libraries for known species in order to foster automated assignment of unknown specimens to known species. For automation purposes, both stability of the reference libraries and reproducibility of the molecular identifications should be guaranteed [182]. For this purpose, the Barcode of Life Datasystem (BOLD) hosts specimen records consisting of seven data elements (Fig. 6):

1. Species name

2. Voucher data

3. Collection record

4. Identifier of the specimen

5. COI sequence of at least $500 \mathrm{bp}$

6. PCR primers used to generate the amplicon

7. Trace files 
These detailed specimens and barcode records ensure the reproducibility of the PCR and sequencing protocols by providing contact of thepeoples involvedingenerating DNA barcodes. In addition, it enables the continuous updating of the identification of specimens by the community of users and facilitates the use of DNA barcodes for further taxonomic studies [21,27-31,183]. To further improve the quality of DNA barcode data, the BARCODE data standard as been implemented in GenBank for the records that are compliant with the following requirements:

1. Bi-directional sequences of at least 500 base-pairs from the approved barcode region of COI, containing no ambiguous sites

2. Links to electropherogram trace files available in the NCBI Trace Archive

3. Sequences for the forward and reverse PCR amplification primers

4. Species names that refer to documented names in a taxonomic publication or other documentation of the species concept used
5. Links to voucher specimens using the approved format of institutional acronym:collection code:catalog ID number.

Altogether, these data allow connecting voucher specimens, further available for screening diagnostic morphological characters anytime undescribed diversity is detected, with DNA barcodes.

\subsection{DNA barcoding: a solution to the taxonomic impediment?}

The broad development of DNA-based assessment of biodiversity opened new perspectives in the inventory of earth living beings [180]. In particular, it has been highlighted through the use of DNA-based approach of species inventories that describing biological diversity with traditional approaches happens at a much slower rate than the rate of species loss [18]. Compared to morphological characters, DNA barcodes presents several advantages: (1) intraspecific phenotypic variation often
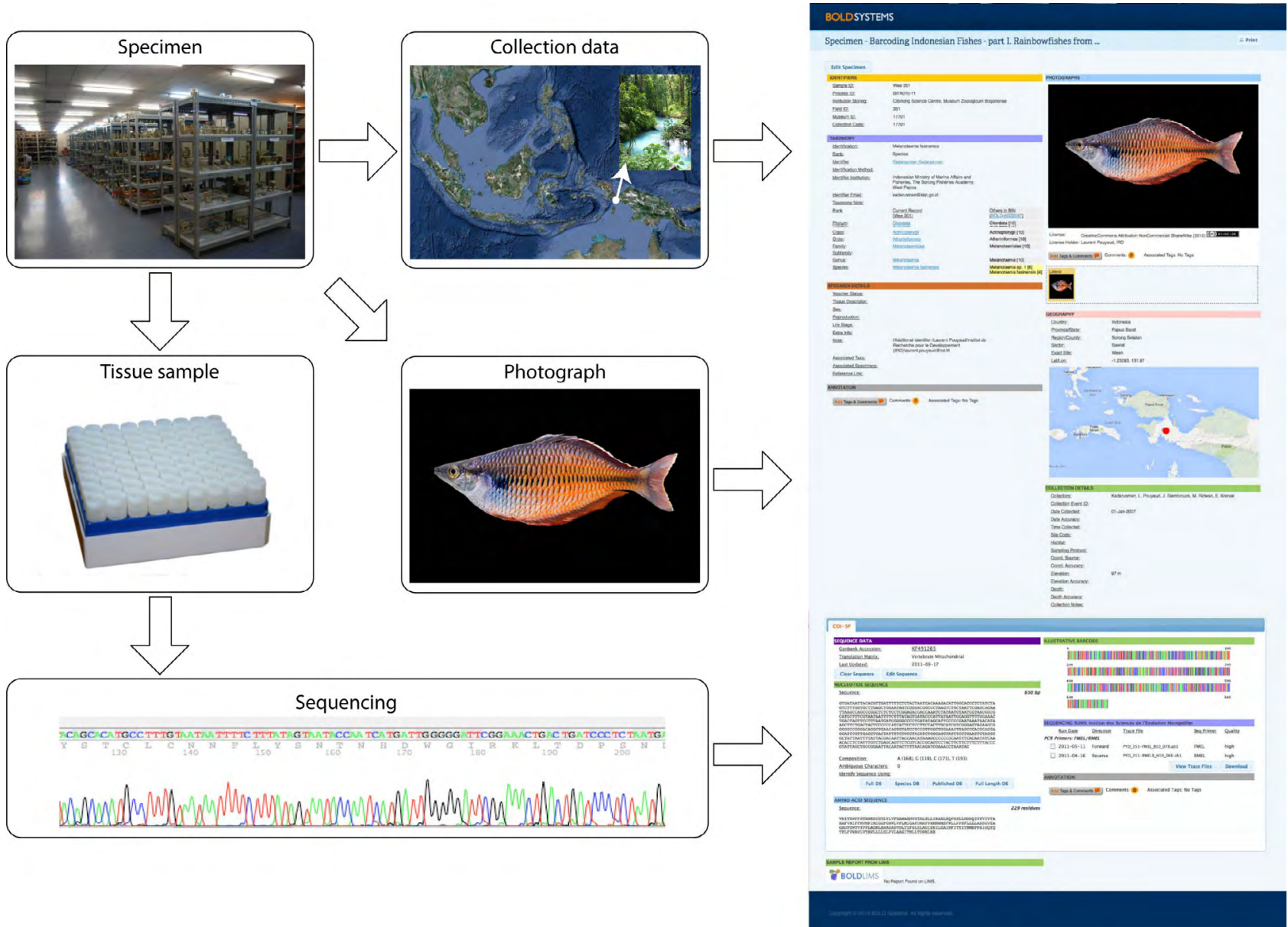

Figure 6. Structure of a specimen record in BOLD. The BARCODE keyword in GenBank is reserved for the records compliant with the following scheme including a voucher specimen in a biological collection, a tissue sample in a bio-repository, collection data, a specimen photograph and a DNA barcode including primary data (e.g. trace files). 
overlaps that of sister taxa in nature, which can lead to incorrect identifications or species delineations [22], (2) DNA barcodes are effective whatever the life stages under scrutiny [24,184]. Recent large-scale DNA barcoding campaigns have demonstrated that DNA barcoding will have to face the undescribed diversity of earth biotas [e.g. 27-29] and that DNA barcodes might help to speed up the pace of species discovery through automated delineation of mitochondrial lineages. This approach is particularly relevant when applied to areas of exceptional diversity facing massive anthropogenic threats and as such, urgently awaiting more comprehensive assessments [1-3,185].

Recently, the effectiveness of such iterative procedures including DNA barcoding, taxonomy and natural history in the delineation of species has been highlighted in speciose communities [27,186-188]. Procedures including DNA barcoding as a first step toward the fast description of species based on the combination of COI sequences, concise morphological descriptions, and high-resolution digital imaging enable the description of larger number of species. In addition, the automated and objective classification of mitochondrial lineages enabled by the use of DNA barcode reference libraries provides a potential solution to the time consuming sorting of specimens during inventories of speciose, yet unknown fauna $[187,188]$. This procedure enables to speed up the taxonomic workflow through a preliminary sorting of specimens according to their DNA barcodes followed by an iterative procedure involving natural history, morphology and DNA barcoding [e.g. 27,189].

Studies based on similar iterative procedures and molecular data compliant with DNA barcode data standard, however, have been scarcely applied during the inventory of the Indonesian ichthyofauna. Kadarusman and colleagues [13,90] pioneered the application of this approach in the Indonesian ichthyofauna and exemplified its benefits by the simultaneous description of eight new species of rainbowfishes from the Papua's bird head based on an initial screening of species diversity through DNA barcodes. Later, Larson and colleagues [85] adopted the same iterative procedure for the Mugilobius of Sulawesi and described a new species. Along the same line, Parenti and colleagues successfully implemented a similar procedure for the Oryzias spp. of Sulawesi and described two new endemic species characterized by both private mitochondrial lineages and diagnostic morphological characters [84]. Such studies have been scarce so far during the ichthyological exploration of the Indonesian inland freshwaters but the ease of access to sequencing facilities may be expected to increase the number of species descriptions based on such iterative procedures.

\subsection{New tools for species identification, environmental DNA barcoding and the management of ichthyological resources}

Recent advances in molecular biology have opened up new perspectives for the management of ichthyological resources, e.g. the possibility to record rare and threatened species, to describe the species composition or to elucidate ecosystem processes from a broad range of environmental samples [190-193]. In contrast with DNA extracted from well-preserved organisms, environmental DNA (eDNA) consists of a mixture of potentially degraded DNA present in trace amounts from many different organisms [190]. Since the long size of the "universal" COI barcode target (658 bp long) is not suitable for a successful amplification of degraded DNA, some authors have introduced a universal "mini-barcode" of $130 \mathrm{bp}$ [194-197] that proved to be particularly effective for the DNA barcoding of old museum specimens. This new approach of monitoring the biodiversity already proved to be effective in a variety of field including functional ecology [e.g. 196,198], biodiversity assessment and environmental inventorying [e.g. 192,199], re-appraisal of archive specimens in natural history museums [e.g. 186,197] and monitoring of the ornamental trade [e.g. 170].

This mini-barcode approach was also recently implemented in a biosecurity perspective for freshwater fish species transiting in the international ornamental trade using eDNA from water of quarantine tanks [170]. In their study, the authors targeted a single species (Danio rerio) and COI was successfully detected at fish densities as low as $0.08 \mathrm{~g} / \mathrm{L}$, further illustrating the potential of this approach as a tool for monitoring quarantine facilities for a variety of invasive and/or endangered species, in the context of the international ornamental fish trade. Here, authors defined a mini-barcode for the species-specific detection of Danio rerio with the use of a sliding window function from the DNA barcoding package Spider [200].

In addition, short-length DNA barcodes have the advantage of better fitting the sequence length of most of the next-generation sequencing (NGS) platforms. NGS is indeed increasingly used to analyze the entire species composition either from pools of entire organisms or from environmental samples. This high-throughput multispecies identification approach was recently designated under the term "DNA metabarcoding" [201]. Proofs of concept of this so-called DNA metabarcoding have been successfully achieved and have shown its 
great potential for deciphering the species richness and composition from a wide variety of samples [191193,198,202]. Addressing the potential of environmental DNA for monitoring rare and threatened freshwater species, Thomsen and colleagues [203] demonstrated that the diversity, and even the abundance, of such species could be monitored from DNA recovered from water samples of ponds, lakes and streams. They also showed that DNA could be detected up to two weeks after animals had been removed from the analyzed water.

Though these new approaches look very promising for the management of Indonesia ichthyological resources (which includes activities as diverse as the assessment of biodiversity, the early detection of invasive species, the monitoring of elusive species or the control of quarantine facilities), yet many questions arise about the accuracy and reliability of environmental DNA barcoding. The primary source of uncertainty comes from the manipulation and processing of eDNA, which require a rigorous standardization and quality control assessment. This seems to be widely acknowledged and solutions to limit these biases have been proposed [see 190,204]. The second source of error lies in the reproducibility of NGS methods, which has not been thoroughly evaluated in the frame of biodiversity assessments. One of the rare studies focusing on this aspect highlighted the necessity to run replicates in order to reduce the risk of misestimating species diversity, particularly in regard to rare taxa [199]. Finally, the accuracy of the DNA-based identifications is tightly dependent on the coverage of the DNA barcode reference libraries used to assign the sequences generated through NGS to known taxa [e.g. 17,21,28,189,205-209].

Whatever the type of sample used, the taxonomic identification of species relies on the ability to match sequences with the DNA barcodes reference librairies. While mini-barcodes are compatible with DNA barcodes data standard (i.e. voucher specimens deposited in formal collections, accessibility to collection metadata) and match the standardized DNA barcode system [181,182,210], yet another major limitation for the implementation of DNA metabarcoding in the management of the Indonesian ichthyodiversity is the necessity to expand the current coverage of those libraries for freshwater fishes beyond those currently available. Worth mentioning, NGS opened new perspectives in the application of routine DNA-based species identification and suggested that DNA sequencing may eliminate the required DNA amplification step [201]. If so, the DNA barcoding reference libraries and their associated data standard will play an increasing role in the future.

\section{Conclusions}

The present review highlights the progress achieved so far on the taxonomic knowledge of the Indonesian ichthyofauna. Nearly 1200 native species have been either reported or described from Indonesian freshwaters but the disrupted flow of taxonomic works during the last centuries and the fast acceleration of the rate of species description during the last decades highlights that much remain to be done. The taxonomy and systematic of many lineages is still pending a major revision and this gap is currently bridling the sustainable management of many species of economic potential for either consumption or the ornamental trade. Considering the fast intensification of the anthropogenic perturbation in Indonesia, filling this gap has become critically important for conservation purposes. DNA barcoding has the potential to help increase rapidly this knowledge and to help promote more sustainable practices in taxonomy through the linkage between traditional and molecular taxonomy with online data systems and the development of new molecular tools for species identification. The main challenge at the moment is the development of comprehensive DNA barcodes reference libraries for the Indonesian ichthyofauna. Given the complex systematic and taxonomy of many freshwater fish lineages at the moment, this review and its associated database in Appendix is expected to help streamlining future campaigns of DNA barcoding in the country.

Acknowledgements: The authors wish to thank Dr. Siti Nuramaliati Prijono, Dr. Tjak Witjaksono, Mohammad Irham, Dr. Marlina Adriyani, Dr. Rosichon Ubaidillah, at Research Centre for Biology (RCB-LIPI), Dr. Jean-Paul Toutain, Dr. Jean-François Agnčse and Dr. Domenico Caruso from the 'Institut de Recherche pour le Développement', and Dr. Bambang Suryobroto at the Bogor Agronomy University for their support. We are thankful to Dr. Daisy Wowor at RCB-LIPI, Sumanta and Bambang Dwisusilo at IRD Jakarta for their help. The authors thank the anonymous referees for their helpful comments. This publication has ISEM number 2015-180 SUD.

Conflict of interest: Authors declare nothing to disclose. 


\section{References}

[1] Myers N., Mittermeier R.A., Mittermeier C.G., da Fonseca G.A.B., Kent J., Biodiversity hotspots for conservation priorities, Nature, 2000, 403, 853-858

[2] Lamoureux J.F., Morrison J.C., Ricketts T.H., Olson D.M., Dinerstein E., McKnight M., et al., Global tests of biodiversity concordance and the importance of endemism, Nature, 2006, 440, 212-214

[3] Hoffman M., Hilton-Taylor C., Angulo A., Böhm M., Brooks T.M., Butchart S.H.M., et al., The impact of conservation on the status of the world's vertebrates, Science, 2010, 330, 1503-1509

[4] Clements R., Sodhi N.S., Schilthuizen M., Ng P.K.L., Limestone karsts of Southeast Asia: Imperiled arks of biodiversity, Bioscience, 2006, 56, 733-742

[5] Schilthuizen M., Liew T.S., Bin Elehan B., Lackman-Ancrenaz I., Effects of karst forest degradation on pulmonate and prosobranch land snail communities in Sabah, Malaysian Borneo, Conserv. Biol., 2005, 19, 949-954

[6] Fraser S., Threats to biodiversity, In: Marshall A.J., Beehler B.M (Eds.), The ecology of Indonesian Papua, Periplus Editions, Singapore, 2006

[7] Normile D., Saving forests to save biodiversity, Science, 2010, 329, 1278-1280

[8] Sodhi N.S., Koh L.P., Clements R., Wanger T.C., Hill J.K., Hamer K.C., et al., Conserving southeast asian forest biodiversity in human-modified landscapes, Biol. Conserv., 2010, 143, 2375-2384

[9] Woodruff D.S., Biogeography and conservation in southeast asia: How 2.7 million years of repeated environmental fluctuations affect today's patterns and the future of the remaining refugium-phase biodiversity, Biodiv. Conserv., 2010, 19, 919-941

[10] Kottelat M., Whitten A.J., Kartikasari S.R., Wirjoatmodjo S., Freshwater fishes of Western Indonesia and Sulawesi, Periplus Editions, Singapore, 1993

[11] Kottelat M., The fishes of the inland waters of southeast asia: A catalog and core bibliography of the fishes known to occur in freshwaters, mangroves and estuaries, Raffles Bull. Zool., 2013, Supplement 27, 1-663

[12] Froese R., Pauly D., Fishbase in Worldwide web electronic publication, http://www.fishbase.org, version (06/2011), 2011

[13] Kadarusman, Hubert N., Hadiaty R.K., Sudarto, Paradis E., Pouyaud L., Cryptic diversity in indo-australian rainbowfishes revealed by DNA barcoding: Implications for conservation in a biodiversity hotspot candidate., PLoS One, 2012, 7, e40627

[14] Hebert P.D.N., Gregory T.R., The promise of DNA barcoding for taxonomy, Syst. Biol., 2005, 54, 852-859

[15] Hebert P.D.N., Cywinska A., Ball S.L., de Waard J.R., Biological identifications through DNA barcodes, Proc. R. Soc. London B, 2003, 270, 313-321

[16] Hebert P.D.N., Stoeckle M.Y., Zemlak T.S., Francis C.M., Identification of birds through DNA barcodes, PLoS Biol., 2004, 2, e312

[17] April J., Mayden R., L., Hanner R.H., Bernatchez L., Genetic calibration of species diversity among north america's freshwater fishes, Proc. Nat. Acad. Sci. USA, 2011, 108, 10602-10607
[18] Blaxter M., Molecular systematics: Counting angels with DNA, Nature, 2003, 421, 122-124

[19] Tautz D., Arctander P., Minelli A., Thomas R.H., Vogler A.P., DNA points the way ahead in taxonomy, Nature, 2002, 418, 479

[20] Tautz D., Arctander P., Minelli A., Thomas R.H., Vogler A.P., A plea for DNA taxonomy, Trends Ecol. Evol., 2003, 18, 70-74

[21] Hebert P.D.N., Penton E.H., Burns J.M., Janzen D.H., Hallwachs W., Ten species in one: DNA barcoding reveals cryptic species in the neotropical skipper butterfly astraptes fulgerator, Proc. Nat. Acad. Sci. USA, 2004, 101, 14812-14817

[22] Packer L., Gibbs J., Sheffield C., Hanner R., DNA barcoding and the mediocrity of morphology, Mol. Ecol. Res., 2009, 9, 42-50

[23] Hubert N., Delrieu-Trottin E., Irisson J.O., Meyer C., Planes S., Identifying early stages of coral reef fishes through DNA barcoding : A test case with the families Acanthuridae and Holocentridae, Mol. Phylogenet. Evol., 2010, 55, 1195-1203

[24] Ko H.-L., Wang Y.-T., Chiu T.-S., Lee M.-A., Leu M.-Y., Chang K.-Z., et al., Evaluating the accuracy of morphological identification of larval fishes by applying DNA barcoding, PLoS One, 2013, 8, e53451

[25] Wong E.H.-K., Hanner R.H., DNA barcoding detects market subtitution in north american seafood, Food Res. Int., 2008, 41, 828-837

[26] Holmes B.H., Steinke D., Ward R.D., Identification of shark and ray fins using DNA barcoding, Fish. Res., 2009, 95, 280-288

[27] Smith A.M., Rodriguez J.J., Whitfield J.B., Deans A.R., Janzen D.H., Hallwachs W., et al., Extreme diversity of tropical parasitoid wasps exposed by iterative integration of natural history, DNA barcoding, morphology, and collections, Proc. Nat. Acad. Sci. USA, 2008, 105, 12359-12364

[28] Smith M.A., Wood D.M., Janzen D.H., Hallwachs W., Hebert P.D.N., DNA barcodes affirm that 16 species of apparently generalist tropical parasitoid flies (Diptera, Tachinidae) are not all generalists, Proc. Nat. Acad. Sci. USA, 2007, 104, 4967-4972

[29] Hubert N., Meyer C., Bruggemann J.H., Guérin F., Komeno R.J.L., Espiau B., et al., Cryptic diversity in indo-pacific coral reef fishes revealed by DNA-barcoding provides new support to the centre-of-overlap hypothesis, PLoS One, 2012, 7, e28987

[30] Jaafar T.N.A.M., Taylor M.I., Mohd Nor S.A., De Bruyn M., Carvalho G.R., DNA barcoding reveals cryptic diversity within commercially exploited Indo-Malay Carangidae (Teleosteii: Perciformes), PLoS One, 2012, 7, e49623

[31] Janzen D.H., Hajibabaei M., Burns J.M., Hallwachs W., Remigio E., Hebert P.D.N., Wedding biodiversity inventory of a large and complex Lepidoptera fauna with DNA barcoding, Phil. Trans. R. Soc. B, 2005, 360, 1835-1845

[32] Eschmeyer W.N., Fricke R., Catalog of fishes - electronic version (updated 6 October 2014) Sciences C.A.o., San Francisco, 2014

[33] Lohman K., De Bruyn M., Page T., Von Rintelen K., Hall R., Ng P.K.L., et al., Biogeography of the Indo-Australian archipelago, Ann. Rev. Ecol.Evol.Syst., 2011, 42, 205-226

[34] De Bruyn M., Rüber L., Nylinder S., Stelbrink B., Lovejoy N.R., Lavoué S., et al., Paleo-drainage basin connectivity predicts evolutionary relationships across three Southeast Asian biodiversity hotspots., Syst. Biol., 2013, 62, 398-410

[35] De Bruyn M., Stelbrink B., Morley R.J., Hall R., Carvalho G.R., Cannon C.H., et al., Borneo and Indochina are major evolutionary hotspots for Southeast Asian biodiversity, Syst. Biol., 2014, 63, 879-901 
[36] Polhemus D.A., Allen G.R., Freshwater biogeography of Papua, In: Marshall A.J., Beehler B.M (Eds.), The ecology of Indonesian Papua, Periplus Editions, Singapore, 2006

[37] Abell R., Thieme M.L., Revenga C., Bryer M., Kottelat M., al. e., Freshwater ecoregions of the world: A new map of biogeographic units for freshwater biodiversity conservation, Bioscience, 2008, 58, 403-414

[38] Wallace A.R., On the zoological geography of the Malay archipelago, J. Proc. Linnean Soc., 1859, 4, 172-189

[39] Weber M., Enkele resultaten der siboga-expeditie.Versl. Gewone vergad. Wis- en natuurk., Afd. K. Akad. Wet. Amsterdam, 1904b, 12, 910-914

[40] Mayr E., Wallace's line in the light of recent zoogeographic studies, Quarterly Rev. Biol., 1944, 19, 1-14

[41] Herder F., Nolte A.W., Pfaender J., Schwarzer J., Hadiaty R.K. Schliewen U.K., Adaptative radiation and hybridization in wallace's dreamponds: Evidence from Sailfin silversides in the Malili Lakes of Sulawesi, Proc. R. Soc. London B, 2006, 273, 2209-2217.

[42] Kottelat M., Britz R., Hui T.H., Witte K.-E., Paedocypris, a new genus of Southeast Asian Cyprinid fish with a remarkable sexual dimorphism, comprises the world's smallest vertebrate, Proc. R. Soc. London B, 2006, 273, 895-899

[43] Conway K.W., Chen W.-J., Mayden R.L., The "Celestial pearl danio" is a miniature Danio (s.S.) (Ostariophysi: Cyprinidae): Evidence from morphology and molecules, Zootaxa, 2008, 1686, 1-28

[44] Britz R., Kottelat M., Hui T.H., Fangfangia spinicleithralis, a new genus and species of miniature Cyprinid fish from the peat swamp forests of Borneo (Teleostei: Cyprinidae), Ichthyol. Expl. Freshwaters, 2011, 22, 327

[45] Britz R., Kottelat M., Paedocypris carbunculus, a new species of miniature fish from Borneo (Teleostei: Cypriniformes: Cyprinidae), Raffles Bull. Zool., 2008, 56, 415-422

[46] Voris H.K., Maps of pleistocene sea levels in southeast asia: Shorelines, river systems and time durations, J. Biogeography, 2000, 27, 1153-1167

[47] Mayden R., Chen W.J., Bart H.L., Doosey M.H., Simons A.M., Tang, K.L., Wood R.M., Agnew M.K., Yang L., Hirt M.V., Clements M.D., Saitoh K., Sado T., Miya M., Nishida M., Reconstructing the phylogenetic relationships of earth's most diverse clade of freshwater fishes - order Cypriniformes (Actynopterygii: Ostariophysi): A case study using multiple nuclear loci and the mitochondrial genome, Mol. Phylogenet. Evol., 2009, 51, 500-514

[48] Chen W.-J., Mayden R.L., Molecular systematics of the Cyprinoidea (Teleostei: Cypriniformes), the world's largest clade of freshwater fishes: Further evidence from six nuclear genes, Mol. Phylogenet. Evol., 2009, 52, 544-549

[49] Mayden R., Chen W.J., The world's smallest vertebrate species of the genus Paedocypris: A new family of freshwater fishes and the sister group of the world's most diverse clade of freshwater fishes (Teleostei: Cypriniformes), Mol. Phylogenet. Evol., 2010, 57, 152-175

[50] Britz R., Conway K.W., Rüber L., Miniatures, morphology and molecules: Paedocypris and its phylogenetic position (Teleostei, Cypriniformes), Zool. J. Linnean Soc., 2014, 172, 556-615

[51] Slechtova V., Bohlen J., Tan H.H., Families of Cobitoidea (Teleostei; Cypriniformes) as revealed from nuclear genetic data and the position of the mysterious genera Barbucca, Psilorhynchus, Serpenticobitis and Vaillantella, Mol. Phylogenet. Evol., 2007, 44, 1358-1365

[52] Chen W.-J., Lheknim V., Mayden R.L., Molecular phylogeny of the Cobitoidea (Teleostei: Cypriniformes) revisited: Position of enigmatic Loach ellopostoma resolved with six nuclear genes, J. Fish Biol., 2009, 75, 2197-2208

[53] Slechtova V., Bohlen J., Freyhof J., Rab P., Molecular phylogeny of the Southeast Asian freshwater fish family Botiidae (Teleostei: Cobitoidea) and the origin of polyploidy in their evolution, Mol. Phylogenet. Evol., 2006, 39, 529-541

[54] Slechtova V., Bohlen J., Perdices A., Molecular phylogeny of the freshwater fish family Cobitidae (Cypriniformes: Teleostei): Delimitation of genera, mitochondrial introgression and evolution of sexual dimorphism, Mol. Phylogenet. Evol., 2008, 47, 812-831

[55] Bohlen J.R., Šlechtová V., Tan H.H., Britz R., Phylogeny of the Southeast Asian freshwater fish genus Pangio (Cypriniformes; Cobitidae), Mol. Phylogenet. Evol., 2011, 61, 854-865

[56] Mayden R.L., Tang K.L., Conway K.W., Freyhof J., Chamberlain S., Haskins M., et al., Phylogenetic relationships of Danio within the order Cypriniformes: A framework for comparative and evolutionary studies of a model species, J. Exp. Zool., 2007, 308B, 642-654

[57] Yang L., Mayden R.L., Sado T., He S., Saitoh K., Miya M., Molecular phylogeny of the fishes traditionally referred to Cyprinini sensu stricto (Teleostei: Cypriniformes), Zoologica Scripta, 2010, 39, 527-550

[58] Tang K.L., Agnew M.K., Chen W.-J., Hirt M.V., Raley M.E., Sado T., et al., Phylogeny of the gudgeons (Teleostei: Cyprinidae: Gobioninae), Mol. Phylogenet. Evol., 2011, 61, 103-124

[59] Saitoh K., Sado T., Doosey M.H., Bart Jr. H.L., Inoue J.G., Nishida M., et al., Evidence from mitochondrial genomics supports the lower mesozoic of South Asia as the time and place of basal divergence of Cypriniform fishes (Actinopterygii: Ostariophysi), Zool. J. Linnean Soc. London, 2011, 161, 633-632

[60] Yang L., Arunachalam M., Sado T., Levin B.A., Golubtsov A.S., Freyhof J., et al., Molecular phylogeny of the Cyprinid tribe Labeonini (Teleostei: Cypriniformes), Mol. Phylogenet. Evol., 2012, 1-29

[61] Tang K.L., Agnew M.K., Hirt M.V., Lumbantobing D.N., Raley M.E., Sado T., et al., Limits and phylogenetic relationships of East Asian fishes in the subfamily Oxygastrinae (Teleostei: Cypriniformes: Cyprinidae), Zootaxa, 2013, 3681, 101

[62] Rüber L., Kottelat, M, Tan, HH, Ng, PKL, Britz, R, Evolution of miniaturization and the phylogenetic position of Paedocypris, comprising the world's smallest vertebrate, BMC Evol. Biol., 2007, 7

[63] Fang F., Norïn M., Liao T.Y., Källersjö M., Kullander S.O., Molecular phylogenetic interrelationships of the South Asian Cyprinid genera Danio, Devario and Microrasbora (Teleostei, Cyprinidae, Danioninae), Zoologica Scripta, 2009, 38, 237-256

[64] Tang K., Agnew, MK, Hirt, MV, Sado, T, Schneider, LM, Freyhof, J, Sulaiman, Z, Swartz, E, Vidthayanon, C, Miya, M, Saitoh, K, Simons, AM, Wood, RM, Mayden, RL, Systematics of the subfamily Danioniae (Teleostei: Cypriniformes: Cyprinidae), Mol. Phylogenet. Evol., 2010, 57, 189-214

[65] Rüber L., Britz R., Zardoya R., Molecular phylogenetics and evolutionary diversification of labyrinth fishes (Perciformes: Anabantoidei), Syst. Biol., 2006, 55, 374-397 
[66] Rüber L., Britz R., Tan H.H., Ng P.K.L., Zardoya R., Evolution of mouthbrooding and life-history correlates in the fighting fish genus Betta, Evolution, 2004, 58, 799-813

[67] Nguyen T.T.T., Na-Nakorn U., Sukmanomon S., ZiMing C., A study on phylogeny and biogeography of mahseer species (Pisces: Cyprinidae) using sequences of three mitochondrial DNA gene regions, Mol. Phylogenet. Evol., 2008, 48, 1223-1231

[68] Pouyaud L., Sudarto, Paradis E., The phylogenetic structure of habitat shift and morphological convergence in Asian Clarias (Teleostei, Siluriformes: Clariidae), J. Zool. Syst. Evol. Res., 2009, 47, 344-356

[69] von Rintelen T., von Rintelen K., Glaubrecht M., Schubart C.D., Herder F., Aquatic biodiversity hotspots in Wallacea - the species flocks in the ancient lakes of Sulawesi, Indonesia, In: Gower G.W., Johnson K.G., Richardson J.E., Rosen B.R., Rüber L., Williams S.T. (Eds.), Biotic evolution and environmental change in Southeast Asia, Cambridge University Press, Cambridge, 2012

[70] Kottelat M., Sailfin silversides (Pisces: Telmatherinidae) of lakes Towuti, Mahalona and Wawontoa (Sulawesi, Indonesia) with descriptions of two new genera and two new species, Ichthyol. Expl. Freshwaters 1990, 1, 35-54

[71] Kottelat M., Sailfin silversides (Pisces: Telmatherinidae) of lake Matano, Sulawesi, Indonesia, with descriptions of six new species, Ichthyol. Expl. Freshwaters, 1991, 1, 321-344

[72] Herder F., Schwarzer J., Pfaender J., Hadiaty R.K., Schliewen U.K., Preliminary checklist of Sailfin silversides (Pisces: Telmatherinidae) in the Malili Lakes of Sulawesi (Indonesia), with a synopsis of systematics and threats, Verh Ges Ichthyol., 2006, 5, 139-163

[73] Herder F., Schliewen U.K., Beyond sympatric speciation: Radiation of Sailfin silverside fishes in the Malili Lakes (Sulawesi), In: Glaubrecht M. (Ed.), Evolution in action adaptive radiations and the origins of biodiversity, Springer, Heidelberg, 2010

[74] Gray S.M., Dill L.M., Tantu F.Y., Loew E.R., Herder F., McKinnon J.S., Environment-contingent sexual selection in a colour polymorphic fish, Proc. R. Soc. London B, 2008, 275, 1785-1791

[75] Pfaender J., Gray S.M., Rick I.P., Chapuis S., Hadiaty R.K., Herder F., Spectral data reveal unexpected cryptic colour polymorphism in female Sailfin silverside fish, Hydrobiologia, 2014, 739, 155-161

[76] Roy D., Docker M.F., Hehanussa P.E., Heath D.D., Haffner G.D., Genetic and morphological data supporting the hypothesis of adaptive radiation in the endemic fish of Lake Matano, J. Evol. Biol., 2004, 17, 1268-1276

[77] Stelbrink B., Ströger I., Hadiaty R.K., Schliewen U.K., Herder F., Age estimates for an adaptive lake fish radiation, its mitochondrial introgression, and an unexpected sister group: Sailfin silversides of the Malili Lakes system in Sulawesi, BMC Evol. Biol., 2014, 14, 94

[78] Schwarzer J., Herder F., Misof B., Hadiaty R.K., Schliewen U.K., Gene flow at the margin of Lake Matano's adaptive Sailfin silverside radiation: Telmatherinidae of River Petea in Sulawesi, Hydrobiologia, 2008, 615, 201-213

[79] Roy D., Paterson, G., Hamilton, P. B., Heath, D. D., Haffner, G. D., Resource-based adaptive divergence in the freshwater fish Telmatherina from Lake Matano, Indonesia, Mol. Ecol., 2007, $16,35-48$
[80] Herder F., Pfaender J., Schliewen U.K., Adaptive sympatric speciation of polychromatic "roundfin" Sailfin silverside fish in Lake Matano (Sulawesi), Evolution, 2008, 62, 2178-2195

[81] Pfaender J., Schliewen U.K., Herder F., Phenotypic traits meet patterns of resource use in the radiation of "sharpfin" Sailfin silverside fish in Lake Matano, Evol. Ecol., 2010, 24, 957-974

[82] Takehana Y., Naruse K., Sakaizumi M., Molecular phylogeny of the medaka fishes genus Oryzias (Beloniformes: Adrianichthyidae) based on nuclear and mitochondrial DNA sequences, Mol. Phylogenet. Evol., 2005, 36, 417-428

[83] Herder F., Hadiaty R.K., Nolte A.W., Pelvic-fin brooding in a new species of riverine ricefish (Atherinomorpha: Beloniformes: Adryanichthyidae) from Tara Toraja, Central Sulawesi, Indonesia, Raffles Bull. Zool., 2012, 60, 267-276

[84] Parenti L.R., Hadiaty R.K., Lumbantobing D., Herder F., Discovery and description of two new ricefishes of the genus Oryzias (Atherinomorpha, Beloniformes, Adrianichthyidae) augments the endemic freshwater fish fauna of Southeastern Sulawesi, Indonesia, Copeia, 2013, 3, 403-414

[85] Larson A., Geiger M.F., Hadiaty R.K., Herder F., Mugilogobius hitam, a new species of freshwater Goby (Teleostei: Gobioidei: Gobiidae) from Lake Towuti, Central Sulawesi, Indonesia, Raffles Bull. Zool., 2014, 62, 718-725

[86] Allen G.R., Rainbowfishes in nature and the aquarium, Tetra Publications, Melle, Germany, 1995

[87] Allen G.R., Renyaan S.J., Three new species of rainbowfishes (Melanotaeniidae) from Irian Jaya, Indoensia, Aqua, Int. J. Ichthyol., 1998, 32, 69-80

[88] Allen A.P., Renyaan S.J., Three new species of rainbowfishes (Melanotaeniidae) from the Triton Lakes, Irian Jaya, New Guinea, Aqua, Int. J. Ichthyol., 1996, 2, 13-24

[89] Allen A.P., Unmack P., Hadiaty R.K., Two new species of rainbowfishes (Melanotaenia: Melanotaeniidae), from Western New Guinea (Papua Barat Province, Indonesia), Aqua, Int. J. Ichthyol., 2008, 14, 209-224

[90] Nugraha M.F.I., Kadarusman, Hubert N., Avarre J.C., Hadiaty R.K., Slembrouck J., et al., Eight new species of rainbowfishes (Melanotaeniidae) from the bird's head region, West Papua, Indonesia, Cybium, 2015, 39, 99-130

[91] Unmack P., Allen G.R., Johnson J.B., Phylogeny and biogeography of rainbowfishes (Melanotaeniidae) from Australia and New Guinea, Mol. Phylogenet. Evol., 2013, 67, 15-27

[92] Allen G.R., Renyaan S.J., Eleotrid fishes of the Triton lakes, Irian Jaya, with descriptions of four new species, Revue Française d'Aquariologie, 1996, 23, 47-56

[93] Allen G.R., Field guide to the freshwater fishes of New Guinea, Christensen Research Institute Publication, Madang, Papua New Guinea, 1991

[94] Allen G.R., Jenkins A.P., Two new species of Mogurnda (Osteichthyes: Eleotrididae) from the Etna Bay region, Irian Jaya, Jndonesia, Ichthyol. Expl. Freshwaters, 1999, 10, 237-246

[95] Allen G.R., Jenkins A.P., Renyaan S.J., Morgurnda wapoga, a new species of freshwater Gudgeon (Eleotridae) from Irian Jaya, Revue Française d'Aquariologie, 1999, 26, 63-66

[96] Adams M., Page T.J., Hurwood D.A., Hughes J.M., A molecular assessment of species boundaries and phylogenetic affinities in Mogurnda (Eleotridae): A case study of cryptic biodiversity in the Australian freshwater fishes, Marine Freshwater Res., 2013, 64, 920-931 
[97] Taillebois L., Maeda K., Vigne S., Keith P., Pelagic larval duration of three amphidromous Sicydiinae gobies (Teleostei: Gobioidei) including widespread and endemic species, Ecol. Freshwater Fish, 2012, 21, 552-559

[98] Lord C., Brun C., Hautecoeur M., Keith P., Insights on endemism: Comparison of the duration of the marine larval phase estimated by otolith microstructural analysis of three amphidromous Sicyopterus species (Gobioidei: Sicydiinae) from vanuatu and new caledonia, Ecol. Freshwater Fish, 2010, 19, 26-38

[99] Sale P.F., Maintenance of high diversity in coral reef fish communities, Am. Natural., 1977, 111, 337-359

[100] Chesson P.L., Warner R.R., Environmental variability promotes coexistence in lottery competitive systems, Am. Natural., 1981, 117, 923-943

[101] Warner R.R., Chesson P.L., Coexistence mediated by recruitment fluctuations: A field guide to the storage effect, Am. Natural., 1985, 125, 769-787

[102] Briggs J.C., Marine zoogeograhy, McGraw Hill, New York, 1974

[103] Briggs J.C., Centrifugal speciation and centres of origin, J. Biogeography, 2000, 27, 1183-1188

[104] Briggs J.C., The marine East Indies: Diversity and speciation, J. Biogeography, 2005, 32, 1517-1522

[105] Bellwood D.R., Hughes T., Regional-scale assembly rules and biodiversity of coral reefs, Science, 2001, 292, 1532-1534

[106] Mora C., Chittaro P.M., Sale P.F., Kritzer J.P., Ludsin S.A., Patterns and processes in reef fish diversity, Nature, 2003, 421, 933-936

[107] Hubert N., Paradis E., Bruggemann J.H., Planes S., Community assembly and diversification in indo-pacific coral reef fishes, Ecol. Evol., 2011, 1, 229-250

[108] Gaither M.R., Rocha L.A., Origins of species richness in the Indo-Malay-Philippine biodiversity hotspot: Evidence for the centre of overlap hypothesis, J. Biogeography, 2013, 40, 1638-1648

[109] Pellissier L., Leprieur F., Parravicini V., Cowman P.F., Kulbicki M., Litsios G., et al., Quaternary coral ree frefugia preserved fish diversity, Science, 2014, 344, 1015-1019

[110] Bellwood D.R., Hughes T.P., Connolly S.R., Tanner J., Environmental and geometric constraints on Indo-Pacific coral reef biodiversity, Ecol. Lett., 2005, 8, 643-651

[111] Colwell R., Lees, DC, The mid-domain effect: Geometric constraints on the geography of species richness, Trends Ecol. Evol., 2000, 15, 70-76

[112] Taillebois L., Castelin M., Lord C., Chabarria R., Dettaï A., Keith P., New Sicydiinae phylogeny (Teleostei: Gobioidei) inferred from mitochondrial and nuclear genes: Insights on systematics and ancestral areas, Mol. Phylogenet. Evol., 2014, $70,260-271$

[113] Keith P., Biology and ecology of amphidromous Gobiidae of the Indo-Pacific and the Caribbean regions, J. Fish Biol., 2003, 63, 831-847

[114] Keith P., Lord C., Systematics of Sicydiinae, In: Patzner R.A., Van Tassell J.L., Kovacic M., Kapoor B.G. (Eds.), The biology of Gobies, Science Publisher Inc., New York, 2011

[115] Keith P., Lord C., Lorion J., Watanabe S., Tsukamoto K., Couloux A., et al., Phylogeny and biogeography of Sicydiinae (Teleostei: Gobiidae) inferred from mitochondrial and nuclear genes, Marine Biol., 2011, 158, 311-326
[116] Keith P., Taillebois L., Status and distribution of Smilosicyopus species (Teleostei, Gobioidei), Cybium, 2014, 38, 69-73

[117] Keith P., Hadiaty R.K., Hubert N., Busson F., Lord C., Three new species of Lentipes from Indonesia (Gobiidae), Cybium, 2014, 38, 133-146

[118] Keith P., Hadiaty R.K., Busson F., Hubert N., A new species of Sicyopus (Gobiidae) from Java and Bali, Cybium, 2014, 38, 173-178

[119] Wibowo A., Bioecology study to determine the course of the giant featherback (Chitala Lopis Bleeker 1851) management in Kampar River, Riau province, Bogor Agricultural University, Bogor, 2011

[120] Rachmatika I., Haryono, Ichthyofauna and fisheries development in Bentuang Karimum National Park (BKNP), West Borneo, Management plan of the BKNP proceeding, ed Herwasono H., WWF-IP, PHPA and ITTO, Jakarta, 1999

[121] Inoue J.G., Kumazawa Y., Miya M., Nishida M., The historical biogeography of the freshwater knifefishes using mitogenomic approaches: A mesozoic origin of the Asian Notopterids (Actinopterygii: Osteoglossomorpha), Mol. Phylogenet. Evol., 2009, 51, 486-499

[122] Sunarno M.T.D., Save giant featherback plasma nuftah, Indonesian Fish. Bull., 2001, 8, 2-6

[123] Fisheries A.f.M.A.a., Statistic of capture by the fisheries of the Riau province, Pekan Baru, Palembang, 2008

[124] Khan M.A., Sinha M., Status of mahseer fisheries in north and north-eastern india with a note on their conservation, J. Inland Fish. Soc. India, 2000, 32, 28-36

[125] Wibowo A., Husna, Genetic structure of the white cyprinid (tor tambroides) from the manna and semanka rivers, inferred from coi gene sequence, Indonesian Fish. Res. J., 2012, 18, 13-17

[126] Ingram B., Sungan G., Gooley S.Y., Sim D., De Silva S.S., Induced spawning, larval development and rearing of two indigenous Malaysian mahseer, Tor tambroides and T. douronensis, Aquaculture Res., 2005, 36, 984-995

[127] Keith P., Hoareau T.B., Lord C., Ah-Yane O., Gimmoneau G., Robinet T., et al., Characterisation of post-larval to juvenile stages, metamorphosis, and recruitment of an amphidromous goby, Sicyopterus lagocephalus (Pallas, 1767) (Teleostei: Gobiidae: Sicydiinae), Marine Freshwater Res., 2008, 59, 876-889

[128] Manacop P.R., The life history and habits of the goby Sicyopterus extraneus herre (Anga) Gobiidae, with an account of the goby-fry fishery of Cagayan River, oriental misamis, Philippine J. Fish., 1953, 2, 1-57

[129] Walter R.P., Hogan J.D., Blum M.J., Gagner R.B., Hain E.F., Gilliam J.F., et al., Climate change and conservation of endemic amphidromous fishes in Hawaiian streams, Endangered Species Res., 2012, 16, 261-272

[130] Olivier K., The ornamental fish market in FAO/Globefish Research Programme, United Nations Food and Agriculture Organisation, Rome, Italy, 2001

[131] Bartley D., Reponsible ornamental fisheries, FAO Aquaculture Newsletter, 2000, 24, 10

[132] Ng P.K.L., Tan H.H., Freshwater fishes of Southeast Asia: Potential for the aquarium fish trade and conservation issues, Aquarium Sci. Conserv., 1997, 1, 79-90

[133] Ng P.K.L., Native southeast asian freshwater fishes conservation of a precarious resource, Role of ASAIHL 
Universities in Promoting Preservation of the Environment, ASAIHL, 373-381, 1991

[134] Ling K.H., Lim L.Y., The status of ornamental fish industry in Singapore, Singapore J. Pri. Ind., 2005, 32, 59-69

[135] Ng P.K.L., Tay J.B., Lim B.K., Diversity and conservation of blackwater fishes in peninsular Malaysia, particularly in the North Selangor peat swamp forest, Hydrobiologia, 1994, 285, 203-218

[136] Hansen M.C., Stehman S.V., Potapov P.V., Arunarwati B., Stolle F., Pittman K., Quantifying changes in the rates of forest clearing in Indonesia from 1990 to 2005 using remotely sensed data sets, Environ. Res. Lett., 4, 2009, doi:10.1088/1748-9326/4/3/034001

[137] Giam X., Koh L.P., Tan H.H., Miettinen J., Tan H.T.W., Ng P.K.L., Global extinctions of freshwater fishes follow peatland conversion in Sundaland, Front. Ecol. Environ., 2012, 10, 465-470

[138] Goh W., Chua J., The Asian Arowana, Industry D.F., Singapore, 1999

[139] Pouyaud L., Sudarto, Teugels, G., G., The different colour varieties of the Asian arowana Scleropages formosus (Osteoglossidae) are distinct species: Morphologic and genetic evidences, Cybium, 2003, 27, 287-305

[140] Legendre M., Satyani D., Subandiyah S., Sudarto, Pouyaud L., Baras E., et al., Biology and culture of the clown loach Chromobotia macracanthus (Cypriniformes, Cobitidae). 1 hormonal induced breeding, unusual latency response and egg production in two populations from Sumatra and Borneo islands, Aquatic Living Resour., 2012, 25, 95-108

[141] Ebner B., Theusen H., Larson A., Keith P., Partially known range and precautionary conservation requirements of Sicydiine gobies in Australia, Cybium, 2012, 35, 397-414

[142] Theusen P.B., Ebner B., Larson A., Keith P., Silcock R., Prince J., et al., Amphidromy links a newly documented fish community of continental Australian streams, to oceanic islands of the West Pacific, PLoS One, 2011, 6, e26685

[143] Maeda K., H. H.T., Review of Stiphodon (Gobiidae: Sicydiinae) from Western Sumatra, with description of a new species, Raffles Bull. Zool., 2013, 61, 749-761

[144] Maeda K., Tachihara K., Diel and seasonal occurrence patterns of drifting fish larvae in the Teima stream, Okinawa Island, Pacific Sci., 2010, 64, 161-176

[145] Talde C.M., Mamaril A.C., Palomares M.L.D., The diet composition of some economically important fishes in the three floodplain lakes in Agusan marsh wildlife sanctuary in the Philippines, Sri Lanka J. Aquatic Sci., 2004, 9, 45-56

[146] Huet M., Aperçu de la pisciculture en indonésie in Bulletin d'Agriculture du Congo Belge, 55, 1956

[147] Setijaningsih L., Zenaiarifin O., Gustiano R., Characterization of three strains of giant gouramy (Osphronemus gouramy Lac) based on truss morphometries method, Jurnal Iktiologi Indonesia, 2007, 7, 23-30

[148] Nuryanto A., Wijayanti G.E., Susilo U., Darsono, Suharno, The failure of partial sequences of cytocrhome $c$ oxidase $i$ sequences on the giant gouramy strains differentiation, Jurnal Iktiologi Indonesia, 2015, in press

[149] Roberts T.R., Vidthayanon C., Systematic revision of the Asian catfish family Pangasiidae, with biological observations and descriptions of three new species, Proc. Acad. Nat. Sci. Philadelphia, 1991, 143, 97-144
[150] Pouyaud L., Teugels G.C., Description of a new pangasiid catfish from east kalimantan, indonesia (siluriformes: Pangasiidae), Ichthyol. Expl. Freshwaters, 2000, 11, 193-200

[151] Pouyaud L., Gustiano R., Teugels G.C., Systematic revision of Pangasius polyuranodon (Siluriformes, Pangasiidae) with description of two new species, Cybium, 2002, 26, 243-252

[152] Pouyaud L., Teugels G.C., Legendre M., Description of a new Pangasiid catfish from South-East asia (siluriformes), Cybium, 1999, 23, 247-258

[153] Gustiano R., Teugels G.C., Pouyaud L., Revision of the Pangasius kunyit catfish complex, with description of two new species from South-East Asia (Siluriformes; Pangasiidae), J. Nat. History, 2003, 37, 357-376

[154] Pouyaud L., Gustiano R., Teugels G.C., Contribution to the phylogeny of the Pangasiidae based on mitochondrial $12 \mathrm{~s}$ rDNA, Indonesian J. Agricult. Sci., 2004, 5, 45-62

[155] Kristanto A.H., Slembrouck J., Legendre M., First sexual maturation and breeding cycle of Pangasius hypophthalmus (Siluriformes, Pangasiidae) reared in pond, Indonesian Fish. Res. J., 2005, 11, 53-57

[156] Slembrouck J., Komarudin O., Maskur, Legendre M., Petunjuk teknis pembenihan ikan patin Indonesia, Pangasius djambal, IRD-PRPB Edisi, Karya Pratama, 2005

[157] Gustiano R., Biometric analysis of the artificial hybridization between Pangasius djambal Bleeker, 1846 and Pangasianodon hypothtalmus Sauvage, 1878, Indonesian J. Agr. Sci., 2004, 5, 70-74

[158] Leprieur F., Beauchard, O, Blanchet, S, Oberdorff, T, Brosse, $S$, Fish invasions in the world's river systems: When natural processes are blurred by human activites, PLoS Biol. 2007, 6, 404-410

[159] Lever C., Naturalized fishes of the world, Academic Press, London, 1996

[160] Blanchet S., Grenouillet G., Beauchard O., Tedesco P.A., Leprieur F., Dürr H.H., et al., Non-native species disrupt the worldwide patterns of freshwater fish body size: Implications for Bergmann's rule, Ecol. Lett., 2010, 13, 421-431

[161] Gozlan R.E., Biodiversity crisis and the introduction of nonnative fish: Solutions, not scapegoats, Fish Fish., 2009, 10, 109-110

[162] Vitule J.R.S., Freire C.A., Simberloff D., Introduction of nonnative freshwater fish can certainly be bad, Fish Fish., 2009, 10

[163] Ng H.H., Clarias insolitus, a new species of Clariid catfish (Teleostei: Siluriformes) from Southern Borneo, Zootaxa, 2003, 284, 1-8

[164] Teugels G.C., Sudarto, Pouyaud L., Description of a new clarias species from Southeast Asia based on morphological and genetical evidence (Siluriformes, Clariidae), Cybium, 2001, 25, 81-92

[165] Sudarto, Teugels G.C., Pouyaud L., Description of two new Clarias species from Borneo (Siluriformes, Clariidae), Cybium, 2003, 27, 153-161

[166] Ng H.H., Hadiaty R.K., Clarias microspilus, a new walking catfish (Teleostei: Clariidae) from Northern Sumatra, Indonesia, J. Threatened Taxa, 2011, 3, 1577-1584

[167] Ng H.H., Clarias microstomus, a new species of Clariid catfish from Eastern Borneo (Teleostei: Siluriformes), Zool. Stud., 2001, 40, 158-162 
[168] Ng H.H., Clarias nigricans, a new species of Clariid catfish (Teleostei: Siluriformes) from Eastern Borneo, Raffles Bull. Zool., 2003, 51, 393-398

[169] Sudarto, Teugels G.C., Pouyaud L., Description of a new Clariid catfish, Clarias pseudonieuhofii from West Borneo (Siluriformes: Clariidae), Zool. Stud., 2004, 43, 8-19

[170] Collins R.A., Armstrong K.F., Meier R., Yi Y., Brown S.D.J., Cruickshank R.H., et al., Barcoding and border biosecurity: Identifying cyprinid fishes in the aquarium trade, PLoS One, 2012, 7, e28381

[171] Liao T.Y., Tan H.H., Brevibora exilis, a new rasborin fish from borneo (teleostei: Cyprinidae), Ichthyol. Expl. Freshwaters, 2014, 24, 209-125

[172] Tweedley J.R., Bird D.J., Potter I.C., Gill H.S., Miller P.J., Donovan G.O., et al., Species compositions and ecology of the riverine ichthyofaunas in two Sulawesian islands in the biodiversity hotspot of Wallacea, J. Fish Biol., 2013, 82, 1916-1950

[173] Herder F., Schliewen U.K., Geiger M.F., Hadiaty R.K., Gray S.M., McKinnon J.S., et al., Alien invasion in wallace's dreamponds: Records of the hybridogenic flowerhorn Cichlid in lake Matano, with an annotated checklist of fish species introduced to the Malili lakes system in Central Sulawesi, Aquatic Inv., 2012, 7, 521-535

[174] Herborg L.-M., Mandrak N.E., Cudmore B.C., Maclsaac H.J., Comparative distribution and invasion risk of snakehead (Channidae) and Asian carp (Cyprinidae) species in North America, 2011, J. Can. Sci. Halieutiques Aquatiques, 12

[175] Roberts T., The freshwater fishes of Western Borneo (Kalimantan Barat, Indonesia), California Academy of Sciences, 1989

[176] Courtenay W.R., Williams J.D., Snakeheads (Pisces, Channidae): A biological synopsis and risk assessment, US Geological Survey, Denver, Colorado, 2004

[177] Li X., Musikasinthorn P., Kumazawa Y., Molecular phylogenetic analyses of snakeheads (Perciformes: Channidae) using mitochondrial DNA sequences, Ichthyol. Res., 2006, 53, 148-159

[178] Adamson E.A.S., Hurwood D.A., Mather P.B., A reappraisal of the evolution of Asian snakehead fishes (Pisces, Channidae) using molecular data from multiple genes and fossil calibration, Mol. Phylogenet. Evol., 2010, 56, 707-717

[179] Serrao N.R., Steinke D., Hanner R., Calibrating snakehead diversity with DNA barcodes: Expanding taxonomic coverage to enable identification of potential and established invasive species, PLoS One, 2014, 9, e99546

[180] Hubert N., Hanner R., DNA barcoding, species delineation and taxonomy: A historical perspective, DNA Barcodes, 2015, 3, 44-58

[181] Hajibabaei M., Singer G.A.C., Hebert P.D.N., Hickey D.A., DNA barcoding: How it complements taxonomy, molecular phylogenetics and population genetics, Trends Ecol. Evol., 2007,

[182] Hubert N., Hanner R.H., Holm E., Mandrak N.E., Taylor E.B., Burridge M., et al., Identifying canadian freshwater fishes through DNA barcodes, PLoS One, 2008, 3, e2490

[183] Steinke D., Zemlak T.S., Hebert P.D.N., Barcoding nemo: DNA-based identifications for the ornamental fish trade, PLoS One, 2009, 4, e6300
[184] Hubert N., Espiau B., Meyer C., Planes S., Identifying the ichthyoplankton of a coral reef using DNA barcodes, Mol. Ecol. Res., 2015, 15, 57-67

[185] Tittensor D.P., Mora C., Jetz W., Lotze H.K., Ricard D., Vanden Berghe E., et al., Global patterns and predictors of marine biodiversity across taxa, Nature, 2010, 466, 1098-1103

[186] Hebert P.D.N., deWaard J.R., Zakharov E., Prosser S.W.J., Sones J.E., McKeown J.T.A., et al., A DNA 'barcode blitz': Rapid digitization and sequencing of a natural history collection, PLoS One, 2013, 8, e68535

[187] Butcher B.A., Smith M.A., Sharkey M.J., Quicke D.L.J., A turbotaxonomic study of thai Aleiodes (Aleiodes) and Aleiodes (Arcaleiodes) (Hymenoptera: Braconidae: Rogadiniae) based largely on coi barcoded specimens, with rapid descriptions of 179 new species, Zootaxa, 2012, 3457, 1-232

[188] Riedel A., Sagata K., Suhardjono Y.R., Tänzler R., Balke M., Integrative taxonomy on the fast track - towards more sustainability in biodiversity research, Front. Ecol., 2013, 10, 15

[189] Collins R.A., Cruickshank R.H., The seven deadly sins of DNA barcoding, Mol. Ecol. Res., 2013, 13, 969-975

[190] Bohmann K., Evans A., Gilbert M.T.P., Carvalho G.R., Creer S., Knapp M., et al., Environmental DNA for wildlife biology and biodiversity monitoring, Trends Ecol. Evol., 2014, 29, 358-367

[191] Andersen K., Bird K.L., Rasmussen M., Haile J., BreuningMadsen H., Kjaer K.H., et al., Meta-barcoding of 'dirt' DNA from soil reflects vertebrate biodiversity, Mol. Ecol., 2012, 21, 1966-1979

[192] Gibson J., Shokralla S., Porter T.M., King I., van Konynenburg S., Janzen D.H., et al., Simultaneous assessment of the macrobiome and microbiome in a bulk sample of tropical arthropods through DNA metasystematics, Proc. Nat. Acad. Sci., 2014, 111, 8007-8012

[193] Hajibabaei M., Shokralla S., Zhou X., Singer G.A.C., Baird D.J., Environmental barcoding: A next-generation sequencing approach for biomonitoring applications using river benthos, PLoS One, 2011, 6, e17497

[194] Meusnier I., Singer G., Landry J.-F., Hickey D., Hebert P., Hajibabaei M., A universal DNA mini-barcode for biodiversity analysis, BMC Genomics, 2008, 9, 214

[195] Hajibabaei M., Smith M.A., Janzen D.H., Rodriguez J.J., Whitfield J.B., Hebert P.D.N., A minimalist barcode can identify a specimen whose DNA is degraded, Mol. Ecol. Notes, 2006, 6, 959-964

[196] Leray M., Yang J.Y., Meyer C., Mills S.C., Agudelo N., Ranwez V., et al., A new versatile primer set targeting a short fragment of the mitochondrial coi region for metabarcoding metazoan diversity: Application for characterizing coral reef fish gut contents., Front. Zool., 2013, 10, 34

[197] Bhattacharjee M.J., Ghosh S.K., Design of mini-barcode for catfishes for assessment of archival biodiversity, Mol. Ecol. Res., 2014, 14, 469-477

[198] Leray M., Agudelo N., Mills S.C., Meyer C., Effectiveness of annealing blocking primers versus restriction enzymes for characterization of generalist diets: Unexpected prey revealed in the gut contents of two coral reef fish species, PLoS One, 2013, 8, e58076

[199] Zhan A., He S., Brown E.A., Chain F.J.J., Therriault T.W., Abbott C.L., et al., Reproducibility of pyrosequencing data for biodiversity assessment in complex communities, Meth. Ecol. Evol., 2014, 5, 881-890 
[200] Brown S.D.J., Collins R.A., Boyer S., Lefort C., MalumbresOlarte J., Vink C.J., et al., Spider: An r package for the analysis of species identity and evolution, with particular reference to DNA barcoding, Mol. Ecol. Res., 2012, 12, 562-565

[201] Taberlet P., Coissac E., Pompanon F., Brochmann C., Willerslev E., Towards next-generation biodiversity assessment using DNA metabarcoding, Mol. Ecol., 2012, 21, 2045 - 2050

[202] Hajibabaei M., De Waard J.R., Ivanova N.V., Ratnasingham S., Dooh R.T., Kirk S.L., et al., Critical factors for assembling a high volume of DNA barcodes, Phil. Trans. R. Soc. B, 2005, 360, 1959-1967

[203] Thomsen P.F., Kielgast J.O.S., Iversen L.L., Wiuf C., Rasmussen M., Gilbert M.T.P., et al., Monitoring endangered freshwater biodiversity using environmental DNA, Mol. Ecol., 2012, 21, 2565-2573

[204] Darling J.A., Mahon A.R., From molecules to management: Adopting DNA-based methods for monitoring biological invasions in aquatic environments, Environ. Res., 2011, 111, 978-988

[205] Smith A.M., Fisher B.L., Hebert P.D.N., DNA barcoding for effective biodiversity assessment of a hyperdiverse arthropod group: The ants of Madagascar, Phil. Trans. R. Soc. B, 2005, $360,1825-1834$
[206] Witt J.D.S., Threloff D.L., Hebert P.D.N., DNA barcoding reveals extraordinary cryptic diversity in an amphipod genus: Implications for desert spring conservation, Mol. Ecol., 2006, 15, 3073-3082

[207] Kerr K.C., Stoeckle M.Y., Dove C.J., Weigt L.A., Francis C.M., Hebert P.D.N., Comprehensive DNA barcode coverage of north american birds, Mol. Ecol. Notes, 2007, 7, 535-543

[208] Rasmussen R.S., Morrissey M.T., Hebert P.D.N., DNA barcoding of commercially important salmon and trout species (Onchorhynchus and Salmo) from North America, J. Agri. Food Chem., 2009, 57, 8379-8385

[209] Wilson J.J., Rougerie R., Schonfeld J., Janzen D.H., Hallwachs W., Hajibabaei M., et al., When species matches are unavailable are DNA barcodes correctly assigned to higher taxa? An assessment using sphingid moths, BMC Ecol., 2011, 11,18

[210] Ratnasingham S., Hebert P.D.N., Bold: The Barcode of Life Data system (http://www.barcodinglife.org), Mol. Ecol. Notes, 2007, 7, 355-364

Supplemental Material: The online version of this article (DOI: 10.1515/dna-2015-0018) offers supplementary material. 